The Free Internet Journal

for Organic Chemistry
Review

Arkivoc 2020, part i, 272-296

\title{
Platinic metal porphyrins and hybrid nanomaterials embedding them as catalysts in chemical transformations
}

\author{
Anca Lascu* \\ Institute of Chemistry "Coriolan Dragulescu" of Romanian Academy, M. Viteazul Ave, No. 24, \\ 300223-Timisoara, Romania \\ Email: ancalascu@yahoo.com, alascu@acad-icht.tm.edu.ro
}

Received 08-05-2020

Accepted 09-15-2020

Published on line $10-02-2020$

\section{Abstract}

The flat geometry of the porphyrin macrocycle and its extended conjugation allows for fine tuning the donating ability of the pyrrole rings via peripheral substituents. Platinic metal complexes with such ligands are thus ideally suited for redox reactions, as well as conventional organic transformations forming C-C bonds. Immobilization of such catalysts on crosslinked organic polymers yields active hybrid nanomaterials which retain significant catalytic activity and may be easily separated from the reaction mixture. Recent applications of both soluble and solid-supported catalysts in this class will be reviewed in this article.

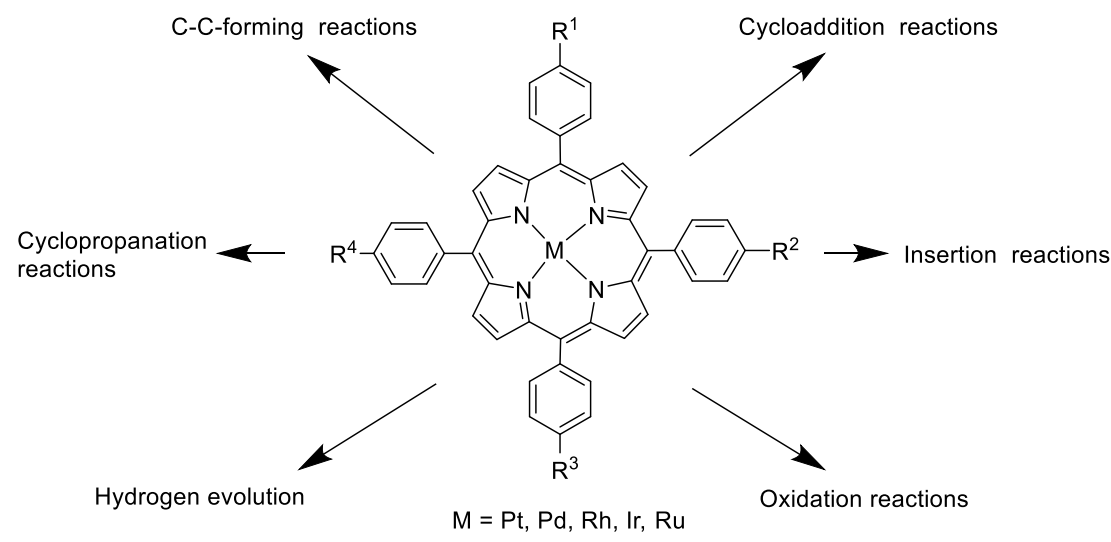

Keywords: Platinic metal porphyrins, hybrid nanomaterials, catalysis, organic transformations 


\section{Table of Contents}

1. Introduction

2. Pd-porphyrins and their Hybrid Nanomaterials Catalysing Organic Reactions

2.1 C-C forming reactions

2.2 Borylation reactions

2.3 Cycloaddition reactions

2.4 Oxidation reactions

3. Hybrid Nanomaterials Containing Rh-, Ru- and Ir-porphyrins as Catalysts in Organic Reactions

$3.1 \mathrm{CO}_{2}$ reduction

3.2 Cyclopropanation reactions

3.3 Hydroxylation of hydrocarbons

3.4 Amination reactions

3.5 Insertion reactions

3.6 Oxidation reactions

4. Hydrogen Evolution and Water Oxidation Catalysed by Pt- and Pd-porphyrin Hybrids

5. Conclusions

6. Acknowledgements

References

\section{Introduction}

Improving the yield of a chemical reaction and reducing the costs by creating milder and more ecological conditions is an ongoing target of researchers all over the world. The main characteristics of a good catalyst are: high activity and selectivity, mechanical and thermal stability, easy separation and recovery, reusability. In the case of the reactions creating new C-C bonds, most catalysts rely on platinic metals, such as: platinum, palladium, rhodium, iridium and ruthenium. The extended aromatic $\pi$-conjugated macrocycles of porphyrins, their capacity for chemical functionalization by peripheral substitution as well as their capacity to accept metal ions in the centre of the molecule, their thermal stability make them excellent candidates to be tested as catalysts in various organic reactions. The porphyrin molecule can be designed such as to accommodate the active metal ion in the most favourable fashion, so that the access of the reacting molecules to the active site of the catalyst is not hindered, and the activity of the metal can also be enhanced by the surrounding substituents.

Platinum is a Group VIII transition metal; the properties of this metal are similar to Pd, even though Pt is larger in size due to its complete $4 \mathrm{f}$ orbital. The position of divalent platinum and palladium cations in the porphyrin molecule varies from within the porphyrin plane to above the plane, and also at the periphery of the macrocycle. The typical geometry of these metalloporphyrins is square planar. ${ }^{1}$ Ruthenium and Rhodium are transition elements with incomplete $4 \mathrm{~d}$ shell, their position in the porphyrin centre favours the binding of axial ligands, thus creating ideal catalytic sites. This review presents some important reactions that are catalyzed by platinic metal porphyrins and some of the best complexes that were used for this purpose. 


\section{Pd-porphyrins and their Hybrid Nanomaterials Catalysing Organic Reactions}

\subsection{C-C Forming reactions}

Reductive Heck reaction between aryl halides and alkenes to form $\mathrm{C}\left(\mathrm{sp}^{2}\right)-\mathrm{C}\left(\mathrm{sp}^{2}\right)$ bonds catalysed by palladium (Scheme 1) is highly enabling because it can forge alkyl-aryl linkages from widely available alkenes, rather than from the less accessible and/or more expensive alkyl halide or organometallic $\mathrm{C}\left(s p^{3}\right)$ synthons that are needed in a classical aryl/alkyl cross-coupling. A general scheme for this $\mathrm{C}-\mathrm{C}$ forming reaction:

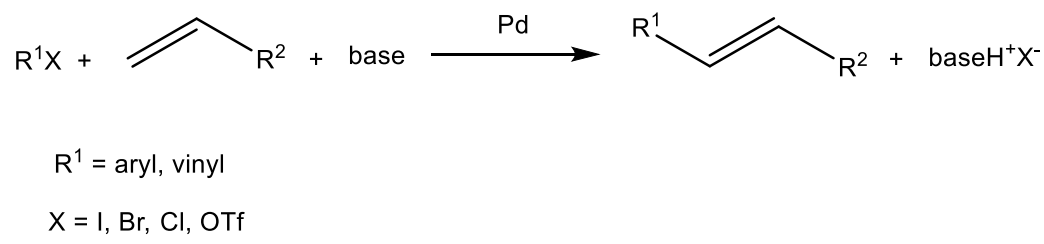

Scheme 1. General Heck reaction.

As the reactivity of aryl halides decreases in the order: $\mathrm{Phl}>\mathrm{PhBr}>>\mathrm{PhCl}$, the need to find more active catalysts for these type of aryl halides lead to the use of phosphine ligands and the increase in temperatures.

The quest for milder conditions and higher turnover numbers, better regioselectivity and efficiency favoured the abundance of palladium-based catalysts tested for this purpose. The optimum form in which palladium active sites are presented to the substrates varies largely in the attempt to prevent deactivation, and $\mathrm{Pd}(\mathrm{II})$-porphyrins were recently tested as thermostable, air insensitive, phosphine-free, recyclable and efficient both homogeneous and heterogeneous catalysts.

The wide use of phosphine ligands for the catalysis of $\mathrm{C}-\mathrm{C}$ coupling reactions stems partly from the electronic factors (in this case P vs N) and partly from the effect phosphine substituents have on the geometry and thus on the donating ability of the phosphorus centre. For instance, it is known that bulky alkyl ligands force a distortion of the typical tetrahedral geometry, changing the hybridization of the central donating atom and significantly increasing its $s$ character. This alters redox potentials and transition state geometries also, markedly affecting the rates of oxidative addition and reductive elimination steps. Bidentate phosphine ligands can magnify these effects even further.

On the other hand, the relatively flat porphyrin ligands have a very limited degree of puckering around the donating environment. They are good ligands only for those atoms which can accommodate geometries such as square planar $\left(s p^{2} d\right.$ hybridization, $\mathrm{D}_{4 \mathrm{~h}}$ symmetry group, coordination number 4$)$ or octahedral $\left(s \mathrm{p}^{3} \mathrm{~d}^{2}, \mathrm{O}_{\mathrm{h}}\right.$ symmetry group, coordination number 6). Open coordination sites and all of the factors mentioned previously are thus altered significantly. It is for this reason that the geometry of the porphyrin ligand, together with its electronic features stemming from the extensive conjugation altering the donating ability of the pyrrole rings, combine to make them more suitable as redox active ligands. This is reflected in HOMO and LUMO relative energies versus those of, for instance, phosphine ligands. Coupling this with extended $\pi$-conjugated systems suitable for light harvesting, or with bi-metal redox ligands of intermediate energies, allows for such reactions as water splitting which no conventional phosphine ligand could achieve. 
Table 1. Catalysts used for the Heck coupling reaction

\begin{tabular}{|c|c|c|c|c|c|c|}
\hline Catalyst & Conditions & $\begin{array}{l}\text { \%mol } \\
\text { catalyst }\end{array}$ & $\begin{array}{c}\text { Yields } \\
\%\end{array}$ & $\begin{array}{l}\text { Reuse } \\
\text { (runs) }\end{array}$ & $\begin{array}{l}\text { Advantages } \\
\text { /disadvantages }\end{array}$ & Ref. \\
\hline $\begin{array}{l}\text { Pd(II) tetra-(N-methyl-4- } \\
\text { pyridinium)porphyrin }\end{array}$ & & & & & $\begin{array}{l}\text {-separation of the catalyst } \\
\text { is difficult }\end{array}$ & \\
\hline $\begin{array}{c}\text { iodide in } N \text {-butylpyridinium } \\
\text { tetrafluoroborate ionic } \\
\text { liquid }\end{array}$ & $100{ }^{\circ} \mathrm{C}, 1 \mathrm{~h}$ & 0.0025 & 100 & 7 & $\begin{array}{l}\text {-the desired products are } \\
\text { contaminated with heavy } \\
\text { metals }\end{array}$ & 2 \\
\hline Porphyrin 2A & $\begin{array}{c}\mathrm{DMF} \\
\mathrm{K}_{2} \mathrm{CO}_{3}(2 \mathrm{mmol}) \\
100{ }^{\circ} \mathrm{C}\end{array}$ & 0.05 & $\begin{array}{l}\text { TON } \\
\text { over } \\
1740\end{array}$ & - & $\begin{array}{l}\text { - high electron density at } \\
\text { the Pd centre favours the } \\
\text { coordination of the metal } \\
\text { to aryl bromides }\end{array}$ & 3 \\
\hline $\begin{array}{l}\text { Porphyrin 2A locked in } \\
\text { mesoporous SBA-15 silica }\end{array}$ & $\begin{array}{l}\mathrm{Et}_{3} \mathrm{~N} \\
140{ }^{\circ} \mathrm{C} \\
4 \mathrm{~h}\end{array}$ & 0.1 & 100 & 9 & $\begin{array}{l}\text { - less effective for } \\
\text { deactivated substrates }\end{array}$ & 4 \\
\hline $\begin{array}{l}\text { Porphyrin 2D grafted on } \\
\text { graphene oxide activated } \\
\text { by (3-chloropropyl)- } \\
\text { trimethoxysilane }\end{array}$ & $\begin{array}{c}\mathrm{DMF}, \\
\mathrm{K}_{2} \mathrm{CO}_{3}(1.5 \mathrm{mmol}), \\
\text { air atmosphere, } \\
120^{\circ} \mathrm{C}\end{array}$ & 10 & $\begin{array}{l}\text { Over } \\
90\end{array}$ & 7 & $\begin{array}{c}\text { - it provides easy } \\
\text { access to the catalytic } \\
\text { sites and fast mass- } \\
\text { transport of the reactants/ } \\
\text { products }\end{array}$ & 7 \\
\hline $\begin{array}{l}\mathrm{Pd}(\mathrm{II}) \text { tetra-(N-methyl-4- } \\
\text { pyridinium)porphyrin } \\
\text { iodide in Dowex 50WX8 }\end{array}$ & $\begin{array}{c}\mathrm{DMF} \\
\mathrm{K}_{2} \mathrm{CO}_{3}(2 \mathrm{mmol}) ; \\
120{ }^{\circ} \mathrm{C}, 25 \mathrm{~min}\end{array}$ & $\begin{array}{c}0.17 \\
\% \mathrm{~mol} \mathrm{Pd}\end{array}$ & 90 & 5 & $\begin{array}{c}\text {-aryl halides with electron- } \\
\text { withdrawing groups are } \\
\text { more reactive }\end{array}$ & 9 \\
\hline $\begin{array}{l}\text { Pd(II) tetra-( } N \text {-methyl-4- } \\
\text { pyridinium)porphyrin } \\
\text { iodide in Amberlite IR-120 }\end{array}$ & $\begin{array}{c}\mathrm{DMF} \\
\mathrm{K}_{2} \mathrm{CO}_{3}(2 \mathrm{mmol}) ; \\
120{ }^{\circ} \mathrm{C}, 38 \mathrm{~min}\end{array}$ & $\begin{array}{c}0.34 \\
\% \mathrm{~mol} \mathrm{Pd}\end{array}$ & 90 & 5 & $\begin{array}{l}\text {-Dowex } 50 \text { WX8 has a } \\
\text { higher porosity }\end{array}$ & 9 \\
\hline $\begin{array}{l}\text { Porphyrin 2F immobilized } \\
\text { on Amberlite IR-120 }\end{array}$ & $\begin{array}{c}\mathrm{DMF}, \\
\mathrm{K}_{2} \mathrm{CO}_{3}(2 \mathrm{mmol}) \\
120^{\circ} \mathrm{C}, 21 \mathrm{~min}\end{array}$ & $\begin{array}{c}0.83 \\
\mathrm{~mol} \% \mathrm{Pd}\end{array}$ & 90 & 5 & $\begin{array}{l}\text {-the starting materials } \\
\text { do not influence the } \\
\text { reaction }\end{array}$ & 10 \\
\hline $\begin{array}{l}\text { Porphyrin } 2 \mathrm{~F} \text { immobilized } \\
\text { on Dowex } 50 \text { WX8 }\end{array}$ & $\begin{array}{c}\mathrm{DMF} \\
\mathrm{K}_{2} \mathrm{CO}_{3}(2 \mathrm{mmol}) \\
120^{\circ} \mathrm{C}, 16 \mathrm{~min}\end{array}$ & $\begin{array}{c}0.75 \\
\mathrm{~mol} \% \mathrm{Pd}\end{array}$ & 95 & 5 & $\begin{array}{l}\text { trans-products with } 100 \% \\
\text { selectivity }\end{array}$ & 10 \\
\hline
\end{tabular}

For example, a catalytic system for the cross-coupling of aryl iodides and ethyl acylate (Heck crosscoupling) was obtained by embedding palladium tetra-( $N$-methyl-4-pyridinium)- porphyrin iodide (Figure 1$)$ in the ionic liquid $N$-butylpyridinium tetrafluoroborate, having similar pyridinium components. ${ }^{2}$ (Table 1 entry 1)The homogeneous catalyst is recyclable but the separation of the expensive catalyst is difficult and the desired products are contaminated with heavy metals. 


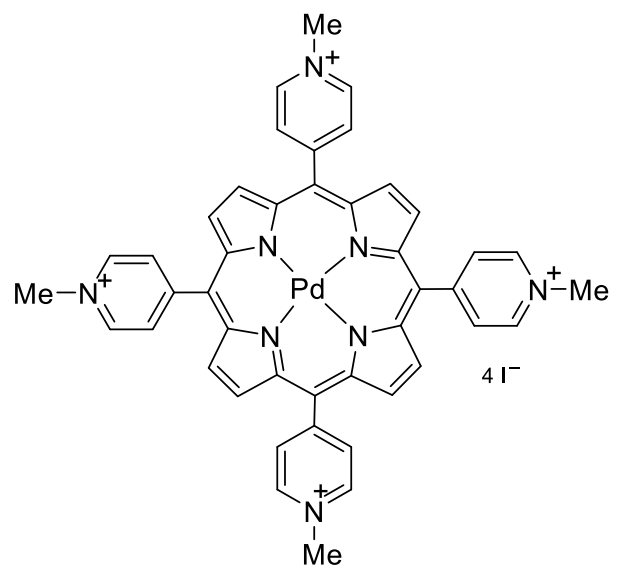

Figure 1. Pd(II) tetra-(N-methyl-4-pyridinium)porphyrin iodide.

The coupling between aryl bromides and alkyl acrylates with the obtaining of alkyl cinnamates (Mizoroki-Heck reaction) was attempted using a variety of palladium-porphyrins: $\mathrm{Pd}(\mathrm{II})$ tetraphenylporphyrin, $\quad \mathrm{Pd}(\mathrm{II})$-tetra(p-cyanophenyl)porphyrin, $\mathrm{Pd}(\mathrm{II})$-tetra(p-anisyl)porphyrin, $\mathrm{Pd}(\mathrm{II})$ tetrasodium tetra(p-sulfonatophenyl)porphyrin (Figure 2A), Pd(II)-tetra(p-tolyl)porphyrin (Figure 2B), $\mathrm{Pd}(\mathrm{II})$-tetra( $m$-hydroxyphenyl)porphyrin, and $\mathrm{Pd}(\mathrm{II})$-tetra( $m$-carboxyphenyl)porphyrin (Figure $2 \mathrm{G})$. $^{3}$ (Table 1 entry 2) As model substrates the authors used 1-bromo-4-nitrobenzene and tert-butyl acetate. The results lead to the conclusion that a high electron density at the palladium centre favours the coordination of the metal to aryl bromides.
$\mathrm{A}: \mathrm{R}=\mathrm{SO}_{3} \mathrm{Na}$
$\mathrm{B}: \mathrm{R}=\mathrm{CH}_{3}$
$\mathrm{C}: \mathrm{R}=\mathrm{O}_{\mathrm{OK}}$
$\mathrm{D}: \mathrm{R}=\mathrm{O}$
$\mathrm{E}: \mathrm{R}=\mathrm{COOCH}_{3}$
$\mathrm{F}: \mathrm{R}=\mathrm{N}^{+}\left(\mathrm{CH}_{3}\right)_{3} \mathrm{I}$
$\mathrm{G}: \mathrm{R}=\mathrm{COOH}$

Figure 2. Pd(II)- A4-substituted porphyrins used as catalysts in organic reactions.

Another method to enhance the activity, stability and reusability of the Pd-porphyrin catalysts is their immobilization upon various thermo- and mechanically stable and porous supports, that enable the access of the reactant molecules to the active site of the Pd-catalyst itself.

A heterogeneous catalyst for the Heck reaction was obtained by functionalization of $N$-methylimidazole with $\mathrm{Pd}(\mathrm{II})$-tetrasodium tetra( $p$-sulfonatophenyl)porphyrin (Figure $2 \mathrm{~A}$ ) (Table 1 entry 3 ) and its subsequent 
locking into the channels of mesoporous SBA-15 silica material. ${ }^{4}$ The imidazolium cations act as linker between the silica material and the anionic porphyrin. The catalyst is efficient for the Heck reaction of aryl iodides/bromides and ethyl acrylate in absence of any organic ligand and organic solvent

Obtaining new $\mathrm{C}-\mathrm{C}$ bonds for the synthesis of complex organic compounds can be performed by the crosscoupling reaction between organic boron compounds and organic halides, known as Suzuki-Miyaura coupling. This synthesis also requires palladium-based catalysts and a base for the activation of the boron compound and can be conducted under mild conditions.

$$
\begin{aligned}
& R^{1}-B_{n}+R^{2}-Y \frac{P d L_{n}}{\text { base }} \rightarrow R^{1}-R^{2} \\
& X_{n}=(O H)_{2},(O R)_{2}, R_{2}, F_{3} K \\
& Y=C l, B r, I, T f O \\
& L_{n}=\text { ligand }
\end{aligned}
$$

Scheme 2. Suzuki-Miyaura coupling: general reaction.

The moisture insensitive, stable and nontoxic $\mathrm{Pd}(\mathrm{II})$-tetra( $p$-tolyl)porphyrin (Figure 2B) (Table 1 entry 1 ) was able to catalyze the formation of new C-C bonds (Suzuki-Miyaura coupling reaction) in one pot. ${ }^{5}$ The best yield (93\%) was obtained for the reaction between 4,4,5,5-tetramethyl-2-(4-nitrophenyl)-1,2,3-dioxaborolane and 4-bromoanisole obtaining pinacol arylboronates with high chemoselectivity. A large variety of substrates was tested and it was concluded that the catalyst presents a high tolerance for different functional groups of the substrate.

In an attempt to replace organic solvents for the Suzuki-Miyaura reaction with water, which enables the simple separation of the homogeneous catalyst, Skondra et al. ${ }^{6}$ obtained a water-soluble potassium carboxylate salt of a $\mathrm{Pd}(\mathrm{II})$-porphyrin possessing butyrate antennae in the para position of the phenyl substituents of the porphyrin ring (Figure 2D) and used it as a pre-catalyst in cross-coupling reactions (Table 1 entry 2).

In order to obtain a heterogeneous catalyst with higher stability and easy recyclability, Bahrami et al. ${ }^{7}$ proceeded to the covalent grafting of $\mathrm{Pd}(\mathrm{II})$-tetra-(p-hexyloxyphenyl)-porphyrin (Figure 2D) to the surface of graphene oxide activated by (3-chloropropyl)trimethoxysilane (Table 1 entry 3 ). This layered material was fully characterized and used as catalyst for Suzuki-Miyaura and Mizoroki-Heck reactions. For the Mizoroki Heck reaction, the aryl halides containing electron-donating groups as well as electron-withdrawing groups could react with styrene in yields of over $90 \%$. The two-dimensional layered structure of the nanomaterial used as catalyst is responsible for its high activity because it provides easy access to the catalytic sites and fast masstransport of the reactants/products.

The carbon-carbon coupling reaction using aryl halides and phenylboronic acid (Suzuki reaction) can be efficiently catalyzed by meso-tetra-[p-(methoxycarbonyl)phenyl]porphyrinato-palladium(II) (Figure 2E) supported on graphene oxide nanosheets. ${ }^{8}$ The palladium porphyrin was immobilized on the surface of the graphene by covalent bonding (Table 1 entry 4) This novel catalyst was fully morphologically characterized. The biphenyl by-product is obtained in $1 \%$. Water helps the process because it attacks the phenylboronic acid and facilitates the elimination of $\mathrm{B}(\mathrm{OH})_{3}$. Some of the advantages of this catalyst are: high specific surface area, thermal and chemical stability, moderate reaction time, high yield, relatively low temperature and no leaching of the palladium. 
Table 2. Catalysts used for the Suzuki-Miyaura coupling

\begin{tabular}{|c|c|c|c|c|c|c|}
\hline Catalyst & Conditions & $\begin{array}{c}\% \text { mol } \\
\text { catalyst }\end{array}$ & $\begin{array}{c}\text { Yields } \\
\%\end{array}$ & $\begin{array}{l}\text { Reuse } \\
\text { (runs) }\end{array}$ & $\begin{array}{c}\text { Advantages } \\
\text { /disadvantages }\end{array}$ & Ref. \\
\hline Porphyrin 2B & $\begin{array}{c}\text { DMF, } \\
\mathrm{K}_{2} \mathrm{CO}_{3} \text { ( } 2 \text { equiv), } \\
3 \mathrm{~h},\end{array}$ & 0.15 & 93 & - & $\begin{array}{l}\text {-nontoxic, moisture } \\
\text { insensitive catalyst } \\
\text {-reaction in one pot } \\
\text { - products are easy } \\
\text { to separate }\end{array}$ & 5 \\
\hline Porphyrin 2D & $\begin{array}{c}\text { Water, } \\
\mathrm{K}_{2} \mathrm{CO}_{3}(2.0 \mathrm{mmol}), \\
100{ }^{\circ} \mathrm{C}\end{array}$ & 0.001 & & - & $\begin{array}{l}\text { - replacing organic } \\
\text { solvents with water } \\
\text {-No recycling, loss of } \\
\text { activity }\end{array}$ & 6 \\
\hline $\begin{array}{l}\text { Porphyrin 2D grafted on } \\
\text { graphene oxide } \\
\text { activated by (3- } \\
\text { chloropropyl)- } \\
\text { trimethoxysilane }\end{array}$ & $\begin{array}{c}\mathrm{EtOH} / \mathrm{H}_{2} \mathrm{O}(2: 1 \mathrm{v} / \mathrm{v}) \\
\mathrm{K}_{2} \mathrm{CO}_{3}(1.5 \mathrm{mmol}) \\
80{ }^{\circ} \mathrm{C}\end{array}$ & $\begin{array}{l}0.1 \mathrm{mmol} \\
\mathrm{Pd}\end{array}$ & 99 & 5 & $\begin{array}{l}\text { - sensitive to the } \\
\text { reaction } \\
\text { temperature }\end{array}$ & 7 \\
\hline $\begin{array}{l}\text { Porphyrin 2E on } \\
\text { graphene nanosheets } \\
\text { by covalent bonding }\end{array}$ & $\begin{array}{c}\mathrm{DMF} / \mathrm{H}_{2} \mathrm{O}=2: 1(\mathrm{v} / \mathrm{v}) \\
\mathrm{K}_{2} \mathrm{CO}_{3}(1.5 \mathrm{mmol}) \\
70{ }^{\circ} \mathrm{C} \\
40 \mathrm{~min}\end{array}$ & $\begin{array}{l}0.7 \% \mathrm{~mol} \\
\mathrm{Pd}\end{array}$ & $\begin{array}{l}\text { Over } \\
92 \%\end{array}$ & 7 & $\begin{array}{l}\text { - Water facilitates } \\
\text { the elimination of } \\
\qquad \mathrm{B}(\mathrm{OH})_{3} .\end{array}$ & 8 \\
\hline $\begin{array}{l}\text { Pd(II) tetra-( } N \text {-methyl- } \\
\text { 4-pyridinium)porphyrin } \\
\text { iodide in Dowex } 50 W \times 8\end{array}$ & $\begin{array}{c}\mathrm{DMF} / \mathrm{H}_{2} \mathrm{O}(2: 1) \mathrm{v} / \mathrm{v} \\
\mathrm{K}_{2} \mathrm{CO}_{3}(1.5 \mathrm{mmol}) \\
95^{\circ} \mathrm{C} \text {-reflux, } 7 \mathrm{~min}\end{array}$ & $\begin{array}{c}0.13 \\
\mathrm{~mol} \% \mathrm{Pd}\end{array}$ & 96 & 5 & $\begin{array}{c}\text {-stability to air and } \\
\text { moisture }\end{array}$ & 9 \\
\hline $\begin{array}{l}\text { Pd(II) tetra-( } N \text {-methyl- } \\
\text { 4-pyridinium)porphyrin } \\
\text { iodide in Amberlite IR- } \\
120\end{array}$ & $\begin{array}{c}\mathrm{DMF} / \mathrm{H}_{2} \mathrm{O}(2: 1) \mathrm{v} / \mathrm{v} \\
\mathrm{K}_{2} \mathrm{CO}_{3}(1.5 \mathrm{mmol}) \\
110{ }^{\circ} \mathrm{C}, 17 \mathrm{~min}\end{array}$ & $\begin{array}{c}0.27 \mathrm{~mol} \% \\
\mathrm{Pd}\end{array}$ & 97 & 5 & $\begin{array}{c}\text { - stability to air and } \\
\text { moisture }\end{array}$ & 9 \\
\hline $\begin{array}{c}\text { Porphyrin 2F } \\
\text { immobilized on } \\
\text { Amberlite IR-120 }\end{array}$ & $\begin{array}{c}\mathrm{DMF} / \mathrm{H}_{2} \mathrm{O}(2: 1 \mathrm{v} / \mathrm{v}) \\
\mathrm{K}_{2} \mathrm{CO}_{3}(1.5 \mathrm{mmol}) \\
110^{\circ} \mathrm{C} \text { under air }\end{array}$ & $\begin{array}{c}0.59 \\
\text { mol\% Pd }\end{array}$ & 97 & 5 & $\begin{array}{l}\text { - Amberlite is a } \\
\text { cross-linked polymer } \\
\text { with more restricted } \\
\text { porosity }\end{array}$ & 10 \\
\hline $\begin{array}{c}\text { Porphyrin } 2 F \\
\text { immobilized on Dowex } \\
50 \mathrm{WX8}\end{array}$ & $\begin{array}{c}\mathrm{DMF} / \mathrm{H}_{2} \mathrm{O}(2: 1 \mathrm{v} / \mathrm{v}) \\
\mathrm{K}_{2} \mathrm{CO}_{3}(1.5 \mathrm{mmol}) \\
95^{\circ} \mathrm{C} \text { under air }\end{array}$ & $\begin{array}{c}0.43 \\
\mathrm{~mol} \% \mathrm{Pd}\end{array}$ & 97 & 5 & $\begin{array}{l}\text {-high thermal } \\
\text { stability }\end{array}$ & 10 \\
\hline
\end{tabular}

Embedding ionic palladium tetra-( $N$-methyl-4-pyridinium)porphyrin iodide (Figure 1 ) into Dowex 50WX8

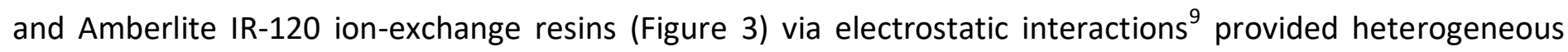


catalysts for the reaction of aryl halides with styrene (Heck reaction) (Table 1 entry 5 and 6) and for the reaction of phenylboronic acid with aryl halides (Suzuki reaction) (Table 2 entry 5 and 6).

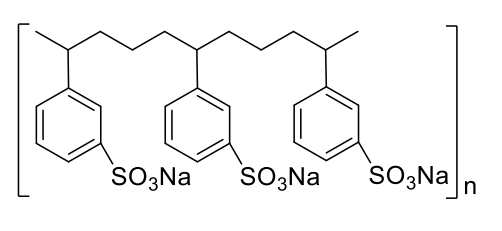

(a)

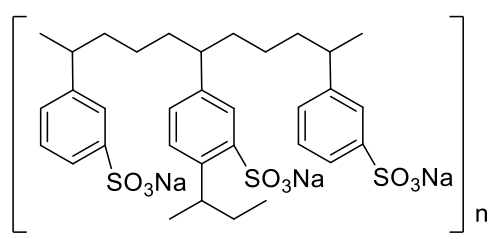

(b)

Figure 3. Structure of (a) Dowex 50WX8 and (b) Amberlite IR-120.

By supporting the porphyrin on the resins, the active sites of the catalyst are isolated and can improve their activity. The variety of aryl halides investigated, good to excellent yields, short reaction times and stability of these systems to air and moisture present advantages of these catalysts. The higher reactivity of the catalyst deposited on Dowex 50 WX8 can be attributed to its different structure and porosity as compared to Amberlite IR-120.

As other supports for the Heck cross-coupling reaction were tested, it was observed that aryl halides with electron-withdrawing groups are more reactive as compared to the aryl halides containing electro-donating substituents and that chloroarenes are less reactive that iodo- and bromo-arenes.

Another ionic Pd-metalloporphyrin, tetrakis $(N, N, N$-trimethyl-ammonium-phenylene)porphyrinato-Pd(II) iodide (Figure 2F), more substituted at the pyridinium nitrogen atom, was also immobilized on Amberlite IR120 and Dowex 50 WX8 resins via electrostatic interactions by the same authors. ${ }^{10}$ The obtained catalysts were characterized by spectroscopic methods and it was confirmed that the immobilized Pd-porphyrin presents a high thermal stability.

For the Heck cross-coupling the optimum parameters are presented in (Table 1 entry 7 and 8).

The Suzuki-Miyaura cross-coupling of 4-iodoanisole with phenylboronic acid was also chosen as model coupling reaction (Table 2 entry 7 and 8). It can be observed that the amount of catalyst required for $96 \%$ yield is higher than in the case of using the $\mathrm{Pd}(\mathrm{II})$ tetra-( $N$-methyl-4-pyridinium)porphyrin iodide, proving the higher activity of the Dowex-supported catalyst, due to the fact that Amberlite is a cross-linked polymer with more restricted porosity. The investigations concerning different substituents on the aromatic rings of the starting materials showed that they do not influence the reaction.

The palladium-active site of the catalyst can also be present outside the porphyrin ring. For example, Osuka et al. ${ }^{11}$ obtained porphyrin-based pincer complexes wherein the palladium is directly attached to a porphyrin carbon atom and to two phosphine donors (PCP-pincer) (Figure 4). The allylation of benzaldehyde with allyltin was chosen as model reaction to test the catalytic capacity of the pincer complex, because it proceeds with maintaining of the valence of the transition metal. The pincer containing $\mathrm{M}=\mathrm{Zn}$ furnished a yield of $97 \%$ yield and when $\mathrm{M}=\mathrm{Ni}$ the yield was $95 \%$, using $1 \mathrm{~mol} \%$ catalyst, 2 mol\% $\mathrm{AgPF}_{6}$, dimethylacetamide as solvent, $100{ }^{\circ} \mathrm{C}$ and $40 \mathrm{~h}$. It can be observed that the amount of catalyst is large, the reaction time lengthy and the required temperature high.

More complex meso-tetra(SCS-pincer PdCl)-metalloporphyrin hybrids (Figure 5) were obtained by Klein Gebbink et al. ${ }^{12}$ In this case the metal centre of the porphyrin was chosen from $\mathrm{Mg}, \mathrm{MnCl}$ and $\mathrm{Ni}$ and the four peripheral metal ions are palladium. The four SCS-pincer ligand groups are substituted thiophenyl groups. The tert-butyl substituents have the purpose of increasing the solubility of the porphyrin. These complexes were used as precatalysts in the Heck reaction between iodobenzene and styrene in DMF at $119{ }^{\circ} \mathrm{C}$ with one equiv. 
of iodobenzene, 1.5 equiv. of styrene, 1.5 equiv. of $\mathrm{Et}_{3} \mathrm{~N}$, and $0.05 \mathrm{~mol} \%$ of the respective pincer porphyrin. Among the investigated metalloporphyrins, the best-performing pincer hybrid coincides with the most electron-rich porphyrin ring, containing $\mathrm{Mg}$, showing that the electron-donating properties of the porphyrin influences the catalytic properties of the peripheral Pd.

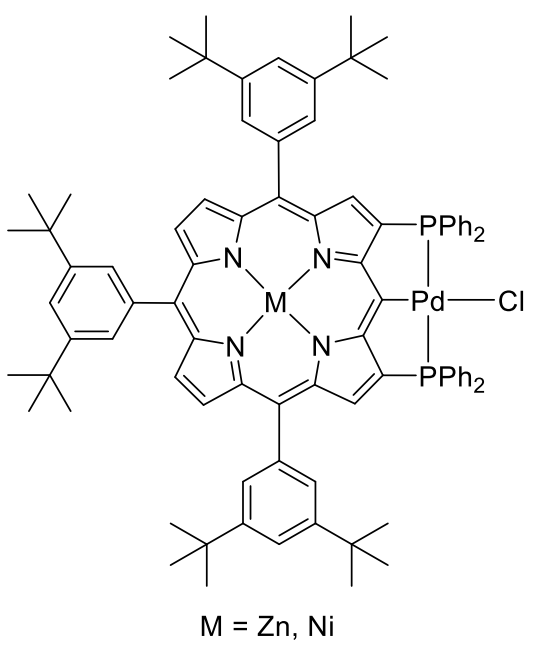

Figure 4. Porphyrin-based PCP pincer complex.

It can be concluded that Pd(II)-tetra-(p-hexyloxyphenyl)porphyrin possessing large substituents (Figure 2D), grafted to the surface of activated graphene oxide ${ }^{7}$ is an excellent choice of catalyst both for the SuzukiMiyaura and for the Mizoroki Heck reactions, as it provides high yields (over 90\%), uses small amounts of catalytic material, mild reaction conditions and good reusability of the heterogenous catalyst. Dowexsupported $\mathrm{Pd}(\mathrm{II})$-porphyrins ${ }^{9,10}$ are also good catalysts for the $\mathrm{C}-\mathrm{C}$ forming reactions, due to their high porosity and the better access of the reacting molecules to the active site of the catalyst.

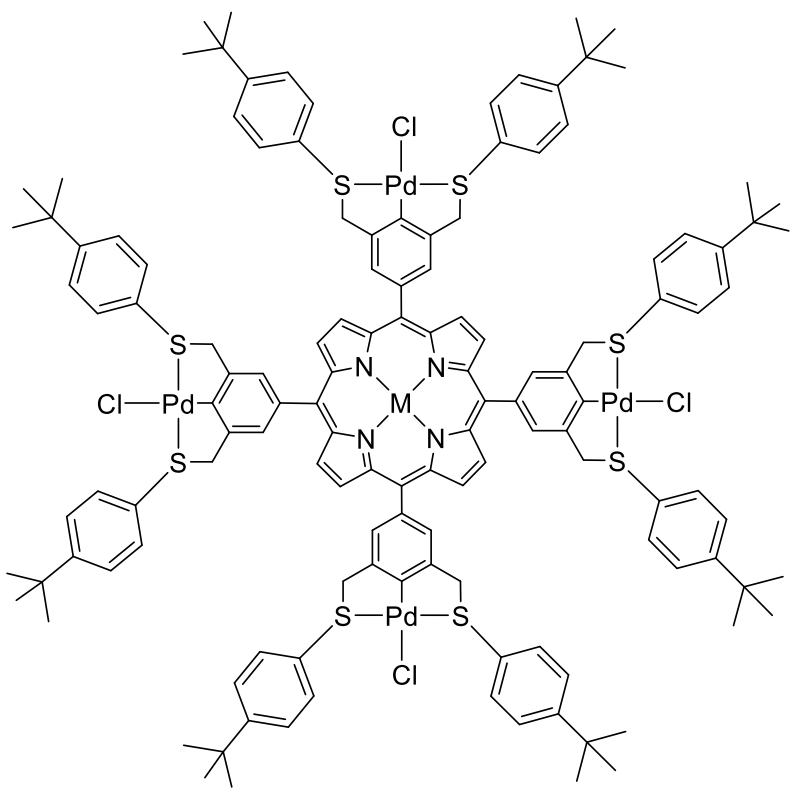

$\mathrm{M}=\mathrm{Mg}, \mathrm{MnCl}, \mathrm{Ni}$

Figure 5. meso-Tetra(2,6-bis[(4-tert-butylphenylsulfido)methyl]-1-chloridopalladio(II)phenyl)metalloporphyrin hybrid. 


\subsection{Borylation reactions}

The Miyaura borylation reaction (Scheme 3) allows the obtaining of boronates. Arylboronate esters of diols or pinacol arylboronates are synthetic building blocks in organic chemistry because of their stability to air, moisture and temperature. They can be used as starting materials for the Suzuki coupling, without prior hydrolysis. The general reaction scheme for aryl halides is:

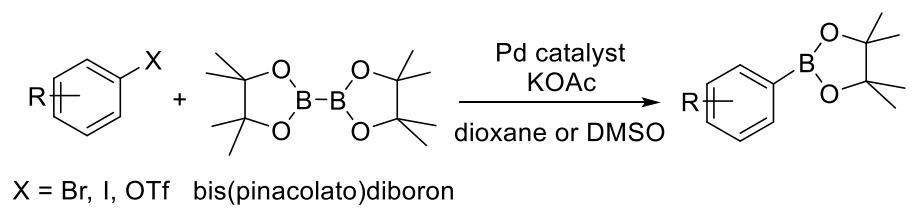

Scheme 3. General Miyaura borylation reaction.

As the palladium-based catalysts involve phosphine-based ligands, that are toxic, expensive and moisture and air sensitive, thus difficult to handle, other catalysts that can offer more stable nitrogen ligands are required.

Several Pd(II)-porphyrins were investigated by Rao et al. ${ }^{13}$ as promising catalyst for the Miyaura borylation: $\mathrm{Pd}(\mathrm{II})$-tetra( $m$-hydroxyphenyl)porphyrin, $\mathrm{Pd}(\mathrm{II})$-tetra(m-carboxyphenyl)porphyrin, $\mathrm{Pd}(\mathrm{II})$-tetraphenylporphyrin, $\mathrm{Pd}(\mathrm{II})$-tetrasodium-tetra( $p$-sulfonatophenyl)porphyrin, $\mathrm{Pd}(\mathrm{II})$-tetra( $p$-cyanophenyl)porphyrin, $\mathrm{Pd}(\mathrm{II})$-tetra( $p$-tolyl)porphyrin and $\mathrm{Pd}(\mathrm{II})$-tetra( $p$-anisyl)-porphyrin. It was concluded that $\mathrm{Pd}(\mathrm{II})$-tetra(p-tolyl)porphyrin (Figure 2B) was the compound that in $0.15 \mathrm{~mol} \%$ gave highest yields when catalysing the reaction between 1-bromo-4nitrobenzene and bis(pinacolato)diborane in the presence of potassium acetate to produce 4,4,5,5tetramethyl-2-(4-nitrophenyl)-1,2,3-dioxaborolane in 92\% yield, in $5 \mathrm{~h}$ in aerobic conditions. The compound $\mathrm{Pd}(\mathrm{II})$-tetraphenylporphyrin shows no catalytic activity, and $\mathrm{Pd}(\mathrm{II})$-tetra( $m$-carboxyphenyl) porphyrin furnishes low yields. The substrates containing electron-withdrawing groups can react better than the electron-rich ones. The authors also proposed a mechanism of action, implying a first step in which a Pd ${ }^{0}$ species is formed.

\subsection{Cycloaddition reactions}

A method to effect the fixation of carbon dioxide and to convert it into high-value products is the epoxide cycloaddition to $\mathrm{CO}_{2}$, when cyclic carbonates, essential materials for the synthesis of polyurethanes, are obtained. Dela Cruz et al. considered the use of $\mathrm{N}$-confused metalloporphyrins as catalysts for such reactions, on the basis that the peripheral nitrogen atom can be functionalized further and the internal carbon atom furnishes carbon-metal bonds. ${ }^{14}$ It was shown that 1,2- epoxy-3-phenoxypropane was converted into 4(phenoxymethyl)-1,3-dioxolan-2-one in an 18-hour interval with a turnover number of 7000 , at $120{ }^{\circ} \mathrm{C}$, in an autoclave, in the presence of 0.015 mol\% of a bifunctional Pd(II)-N-confused tetraphenylporphyrin (Figure 6) as catalyst, $6 \mathrm{~mol} \%$ of triethylamine and $\mathrm{CO}_{2}$ pressure of $0.98 \mathrm{MPa}$, in solvent-free conditions (scheme 4).

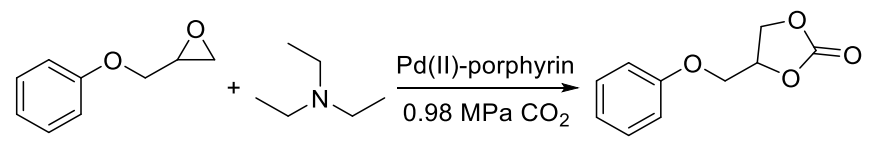

Scheme 4. Cycloaddition reaction. 
It was suggested that the epoxide ring is activated both by the metal centre and the peripheral carboxylate group. Higher yields are obtained for epoxides that have electron-withdrawing substituents or substituents capable of van der Waals interactions with the peripheral functionality of the catalyst. Nevertheless, the authors attempted the introduction of a less expensive and more ecologically-benign metal in the core of the $\mathrm{N}$-confused porphyrin ring, namely $\mathrm{Ni}$, with the correction that 2,6-lutidine was introduced as the deprotonating base. Good yields (TON of up to 6500) were also obtained in this instance.

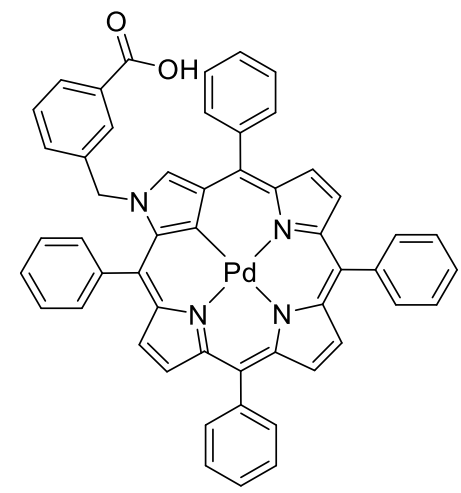

Figure 6. $\mathrm{Pd}(\mathrm{II})-\mathrm{N}$-confused tetraphenylporphyrin

\subsection{Oxidation reactions}

Another type of organic reaction that needs catalysts for control of the selectivity is oxidation. The selective oxidation of styrene to acetophenone and benzaldehyde (Scheme 5) was obtained for example using a metalorganic framework (MOF) that consists in Pd(II)-tetra(carboxyphenyl)porphyrin (Figure 2G) and cadmium(II) connecting nodes. ${ }^{15}$

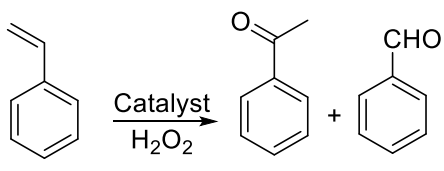

Scheme 5. Oxidation of styrene.

Each Pd-porphyrin molecule acts as an octa-dentate ligand to coordinate eight Cd atoms of four neighbouring $\mathrm{Cd}$ chains into a three-dimensional structure. The oxidation reactions take place in acidic conditions, the nature and quantity of the acid determines the yield in acetophenone. The required temperature is $55^{\circ} \mathrm{C}$ and the conversion is $100 \%$ after $12 \mathrm{~h}$. The MOF offered high stability, easy separation and recyclability.

The photoinduced oxidative functionalization of tertiary amines and the photochemical oxidation of sulfides to sulfoxides were achieved using $\mathrm{Pt}(\mathrm{II})$-tetra(pentafluorophenyl)porphyrin and $\mathrm{Pd}(\mathrm{II})$ tetra(pentafluorophenyl)porphyrin (Figure 7) as efficient and robust catalysts. ${ }^{16}$ These compounds were chosen because of their strong absorption in the visible region, long-lived triplet excitation states and their stability to oxidative degradation. It was concluded that both perfluorinated metalloporphyrins are able to catalyse the light-induced aerobic oxidation of dibenzylamine to the corresponding imine in over $98 \%$ yield, within $2.5 \mathrm{~h}$, despite the fact that the catalyst loading is very low $(0.005 \mathrm{~mol} \%)$. The irradiation took place with visible light wavelengths $(\lambda=400 \mathrm{~nm})$ in aerobic conditions, in MeCN as solvent. The mechanism of the 
oxidation was also proposed, as the photochemically generated singlet oxygen induces the oxidation of amine to iminium ion intermediate and this reacts with nucleophiles to give the corresponding products.

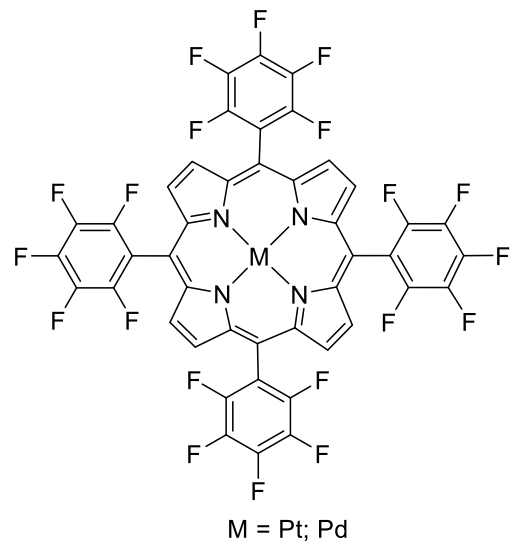

Figure 7. M(II)-tetra(pentafluorophenyl)porphyrin.

\section{Hybrid Nanomaterials Containing Rh-, Ru- and Ir-porphyrins as Catalysts in Organic Reactions}

An extensive review covering Rh-porphyrins was published in 2018 , by Dong et al. ${ }^{17}$ The synthesis, properties, transformations and applications of various Rh-porphyrins were presented.

\section{1. $\mathrm{CO}_{2}$ reduction}

More recent work regarding the use of hybrid nanomaterials containing Rh-porphyrins as catalysts in organic reactions was presented by Su et al. ${ }^{18}$ They obtained a metal-organic framework (MOF) by self-assembling $\mathrm{Rh}$ (III)-tetra(p-carboxyphenyl)porphyrin chloride (Figure 8) with $\mathrm{ZrCl}_{4}$. This metal-organic framework contains single-sited unsaturated Rh-porphyrin units and was used as selective photocatalyst for $\mathrm{CO}_{2}$ reduction to formate ion. The reduction of $\mathrm{CO}_{2}$ was carried out using acetonitrile as reaction solvent and triethanolamine as sacrificial agent, under visible light irradiation $(\lambda \geq 400 \mathrm{~nm})$ in the absence of additional photosensitizer.

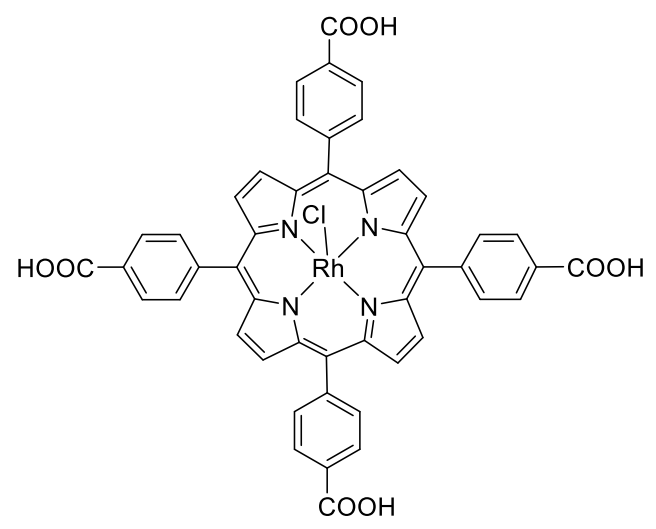

Figure 8. Rh(III)-tetra(p-carboxyphenyl)porphyrin chloride. 
The amount of formate ion reached $6.1 \mu \mathrm{mol} / \mu \mathrm{mol}_{\text {cat }}$ in $18 \mathrm{~h}$ exposure to visible light irradiation and a turnover frequency of $0.34 \mathrm{~h}^{-1}$, comparable to that of other MOF-based catalysts, MOF-253-Ru(CO) ${ }_{2} \mathrm{Cl}_{2}{ }^{19} \mathrm{TTe}^{1}$ selectivity of the reduction reaction resides in the fact that this Rh-porphyrin containing MOF has adequate adsorption capacity both for $\mathrm{CO}_{2}$ and for $\mathrm{CO}$, with strong bonds between $\mathrm{CO}$ and the Rh atoms and the $\mathrm{CO}_{2}{ }^{\bullet}$ activated intermediate can combine easier with a hydrogen atom to form the formate ion. The robust and heterogeneous photocatalyst can be reused three times without loss of activity.

\subsection{Cyclopropanation reactions}

Obtaining the strained rings present in cyclopropanes requires highly reactive species, such as carbenes, ylids and carbanions on one of the reagents, both new bonds are being made to the same atom. Cyclopropanation of double bonds is usually catalysed by transition metals, especially Rh (II, III) compounds. The proven stability, recyclability along with the pocket-like environment around the catalytically active metalloporphyrin centre motivated Fischer et al. ${ }^{20}$ to test Rh-porphyrin-containing metal-organic frameworks as heterogenous catalysts for the cyclopropanation of olefins with ethyl diazoacetate. The metal-organic frameworks were obtained from saponified tetra(p-methoxycarbonylphenyl)porphyrinato-Rh(III) chloride and $\mathrm{ZrCl}_{4}$ [PCN-224(Rh)] and from [tetra(p-carboxyphenyl)porphyrin-Rh(III) chloride (Figure 9) and $\mathrm{ZrCl}_{4}$ [PCN-222(Rh)] respectively, by solvothermal synthesis in benzoic acid as modulator. The two MOF-s differ in pore geometry and topology and in the Rh-Rh distance, that for PCN-224(Rh) is $13.6 \AA$ and for PCN-222(Rh) is $9.7 \AA$, but the Zr-Rh distances in both MOFs are identical. The authors optimized the conditions, using catalyst loadings of $0.0033 \mathrm{mmol}(0.4$ mol\% Rh), excess olefin and a motorized pump for the introduction of ethyldiazoacetate in order to improve the yields. An extensive study regarding various olefin substrates and the catalyst-topology-dependent diastereoselectivity of the reactions is also presented.

Axial $\mathrm{N}$-heterocyclic carbene (NHC) ligands on Ru-porphyrins are increasingly used in catalysis. Che et al. synthesized a series of ruthenium porphyrins having $\mathrm{N}$-heterocyclic carbenes as axial ligands and tested them for a series of organic reactions such as: alkene cyclopropanation, carbene $\mathrm{C}-\mathrm{H}, \mathrm{N}-\mathrm{H}, \mathrm{S}-\mathrm{H}$, and $\mathrm{O}-\mathrm{H}$ insertion, alkene aziridination, and nitrene $\mathrm{C}-\mathrm{H}$ insertion. ${ }^{21}$ Owing to the strong donor strength of NHC ligands, these complexes show high catalytic activity towards alkene cyclopropanation, carbene $\mathrm{C}-\mathrm{H}, \mathrm{N}-\mathrm{H}, \mathrm{S}-\mathrm{H}$, and $\mathrm{O}-\mathrm{H}$ insertion, alkene aziridination, and nitrene $\mathrm{C}-\mathrm{H}$ insertion with turnover frequencies up to $1950 \mathrm{~min}^{-1}$. The trans axial NHC ligand facilitates the decomposition of diazo compounds by stabilizing the metal-carbene reaction intermediate.

The catalytic cyclopropanation reaction (Scheme 6) of $1.6 \mathrm{mmol}$ alkenes with $0.8 \mathrm{mmol}$ ethyl diazoacetate, using $0.0004 \mathrm{mmol} \quad \mathrm{Ru}(\mathrm{IV})$-[tetra(4-fluorophenyl)porphyrin](1,3-dimethyl-2,3-dihydro-1H-benzimidazol-2ylidene) ${ }_{2}$ (Figure 15) as catalyst, in $1 \mathrm{~mL} \mathrm{CH}_{2} \mathrm{Cl}_{2}$ proved to be the best reaction conditions, that led to yields higher than $78 \%$ after 20 minutes reaction time and a trans/cis ratio of $17 / 1$ of the obtained products.

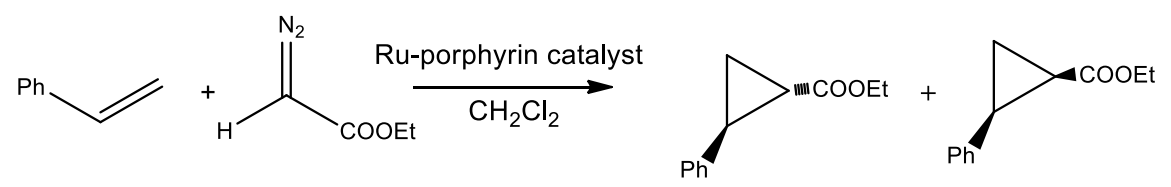

Scheme 6. General cyclopropanation of styrene 


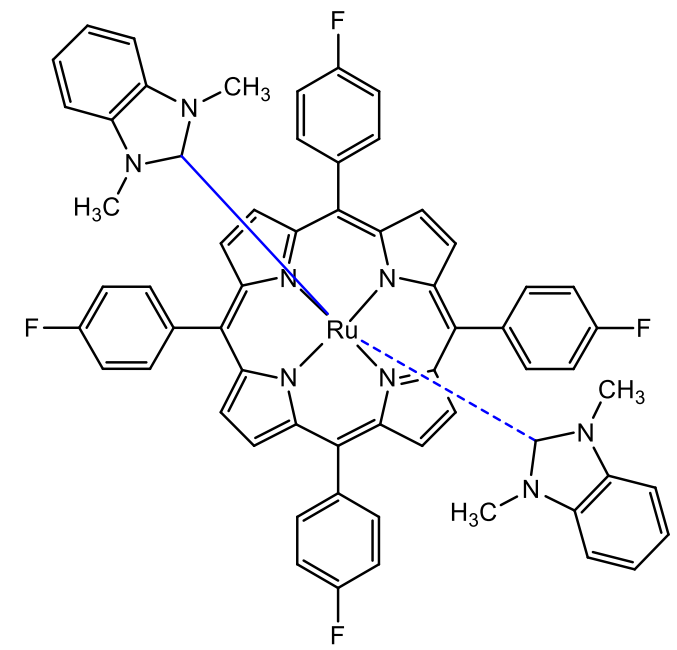

Figure 9. Ru(IV)-tetra(p-fluorophenyl)porphyrin)(1,3-dimethyl-2,3-dihydro-1H-benzimidazol-2-ylidene) ${ }_{2}$.

The reaction between styrene and ethyl diazoacetate in water to give cyclopropane esters was conducted with water soluble, optically active ruthenium porphyrins with yield $85 \%$, high diastereoselectivity (trans/cis: 92/8) and good enantioselectivity for the trans isomer (83\%). ${ }^{22}$ The porphyrin possesses as substituents C2-symmetric groups which contain two norbornane groups fused to the central benzene ring Halterman porphyrin. The sulfonated Halterman porphyrin (Figure 10) is water-soluble, optically active and can be reused as catalyst for four cycles.

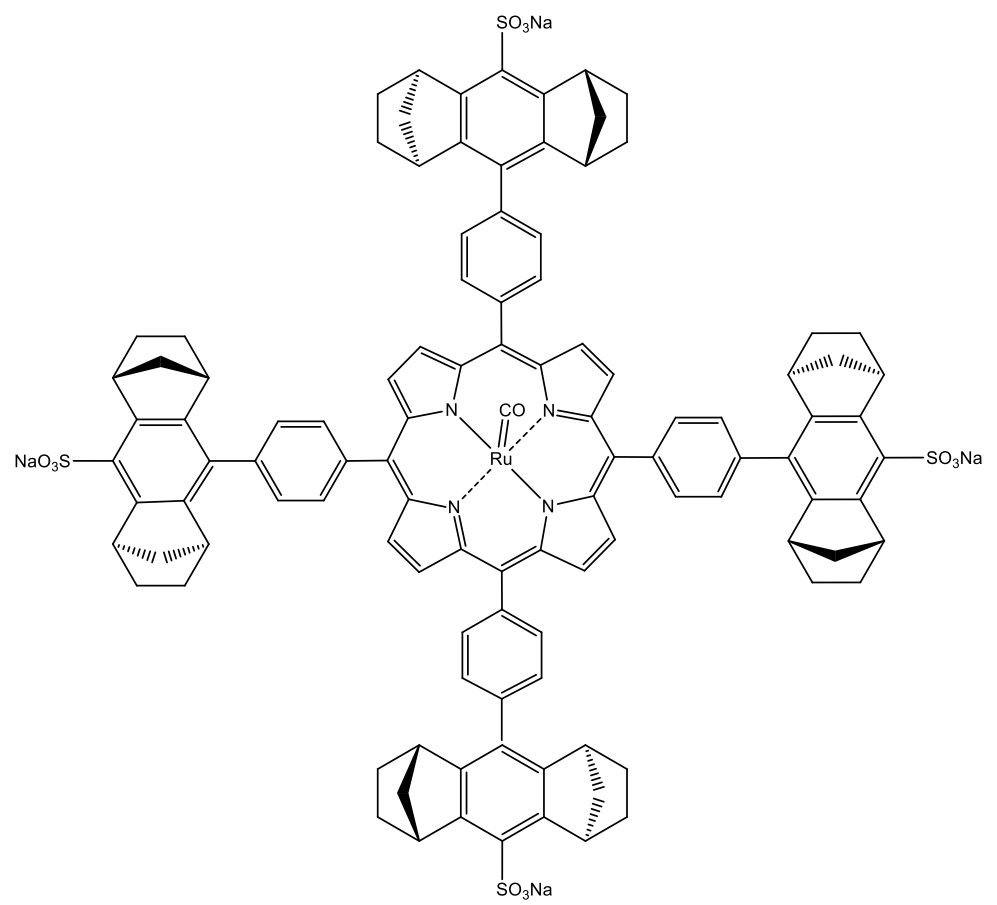

Figure 10. Sulfonated Halterman porphyrin.

The ruthenium complexes of phthalocyanine macrocycles have robust chemical properties and are therefore good candidates as catalytic systems for cyclopropanation of styrenes and in the carbene insertion to $\mathrm{N}-\mathrm{H}$ bond of anilines using ethyl diazoacetate (EDA) as a carbene donor. Sorokin et al. ${ }^{23}$ obtained Ru(III)-and $\mathrm{Ru}(\mathrm{IV})$-octa- $n$-butoxyphthalocyanine complexes from $\mathrm{Ru}_{3}(\mathrm{CO})_{12}$ and the corresponding octa- $n$-butyloxy- 
phthalocyanine under reflux in $o$-dichlorobenzene. The obtained products included a monomeric Ru(III) complex having a CO molecule axially coordinated and a dimeric phthalocyaninato-Ru(IV) complex with $\mu$-carbido bridge having a sandwich-like structure (Figure 11). This $\mu$-carbido diruthenium complex was used as catalyst for the cyclopropanation of olefins by EDA and yields of $100 \%$ were obtained for substrates like $p$ methoxystyrene and 1,1-diphenylethene in toluene under argon, at $90{ }^{\circ} \mathrm{C}$, in 6 hours. The reaction of $\mathrm{N}-\mathrm{H}$ insertion of EDA to amines catalysed by $\mu$-carbidodiruthenium complex yielded $100 \%$ product when starting from aniline, $p$-methylaniline and $p$-chloroaniline in toluene at $90{ }^{\circ} \mathrm{C}$.

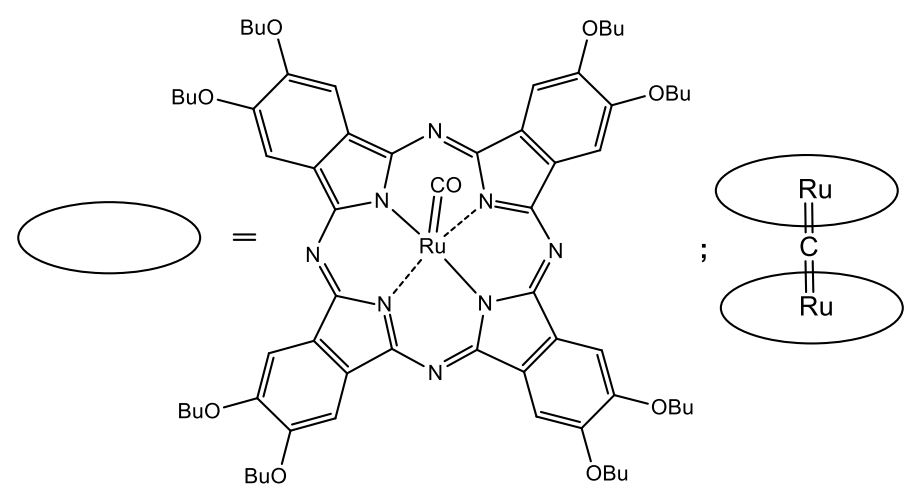

Figure 11. Monomeric octabutoxyphthalocyaninatoruthenium(II) carbonyl complex and dimeric $\mu$-carbidobis[octabutoxyphthalocyaninatoruthenium(IV)] complex.

Metalloporphyrin complexes with 2-adamantylidene axial ligands (Figure 12) display thermal and chemical stability due to the synergistic effect of the metal-carbene bond. ${ }^{24}$ This type of compounds can act as catalysts for intermolecular diarylcarbene transfer reactions including cyclopropanation and $X-H(X=S, N, O, C)$ insertion reactions. The best yields are provided by the compounds containing Fe as central metal ion, but the Ru-containing compound reached $92 \%$ yield in catalysing carbene transfer reactions, under mild conditions: dichloromethane, $40{ }^{\circ} \mathrm{C}$ and 12 hours.
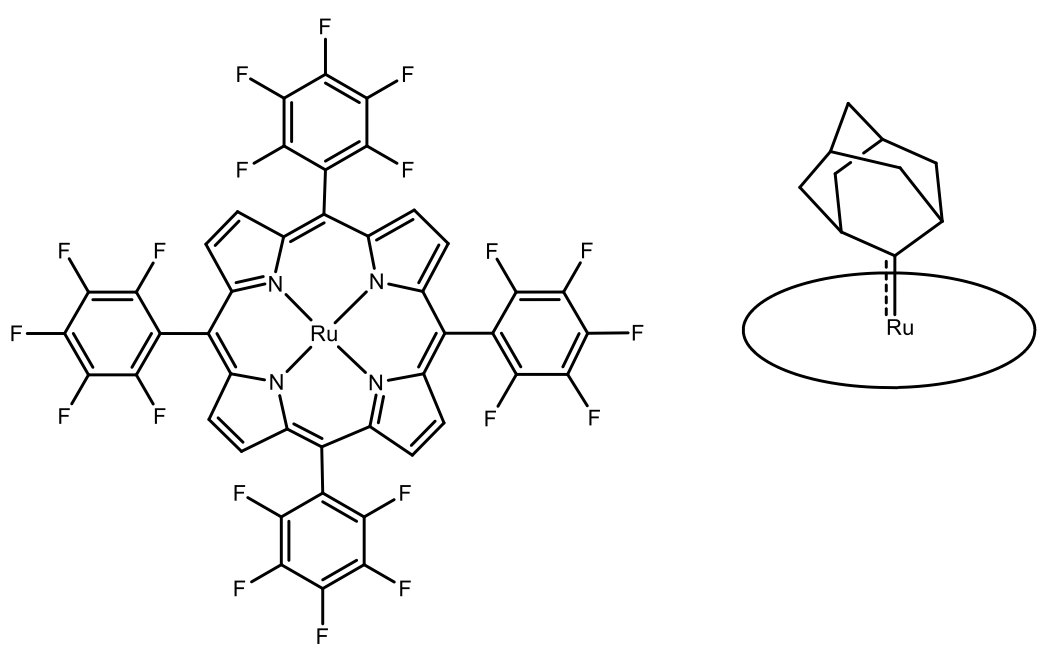

Figure 12. Ru(IV)-tetra(pentafluorophenyl)porphyrin having a 2-adamantylidene axial ligand.

An extensive review concerning the synthesis, structure, reactivity and catalytic activity of carbene Ru/Os porphyrins was presented by Che and Huang. ${ }^{25}$ The porphyrin ligands are meso-tetraarylporphyrinato 
dianions. The structures of the $\mathrm{Ru}$ and $\mathrm{Os}$ porphyrin carbene complexes were characterized by $\mathrm{X}$-ray diffraction and mass spectrometry. It was concluded that they are active intermediates toward catalytic cyclopropanation of alkenes or stoichiometric saturated $\mathrm{C} / \mathrm{H}$ insertion of unfunctionalized alkenes and the first examples of metalloporphyrin carbene complexes that bear monosubstituted carbene groups $\mathrm{CHR}$, or contain multiple carbene ligands at the axial sites.

\subsection{Hydroxylation of hydrocarbons}

An extensive study regarding the hydroxylation of hydrocarbons with 2,6-dichloropyridine $\mathrm{N}$-oxide as oxidant was performed by using ruthenium complexes of tetra(pentafluorophenyl)porphyrin (Figure 13) as catalysts. ${ }^{26}$ High turnover numbers were reported, up to 14800 in the case of adamantane as substrate. The authors used mild reaction conditions $\left(\mathrm{CH}_{2} \mathrm{Cl}_{2}\right.$ solvent, highest temperature $\left.65^{\circ} \mathrm{C}\right)$ and small quantities of catalyst $\left(1 \times 10^{-8}\right.$ $\mathrm{M})$ for the reaction. The proposed mechanism of reaction implies a fast cycle involving metastable Ru(III) and oxoRu(V) intermediates and a slow oxidation cycle, mediated by oxoRu(IV) and trans-dioxoRu(VI) porphyrin complexes.

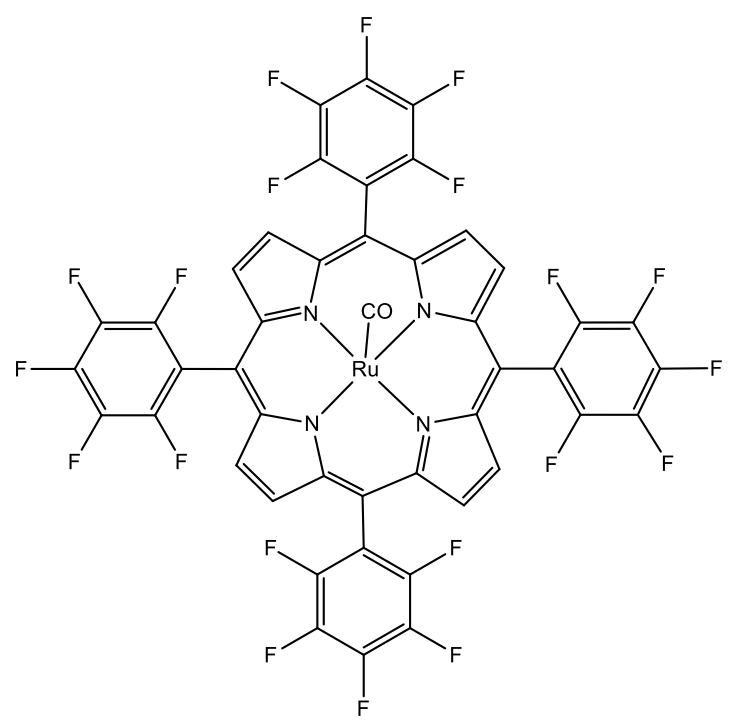

Figure 13. Ruthenium (II)-tetra(pentafluorophenyl)porphyrin carbonyl.

\subsection{Amination reactions}

The direct transfer of a nitrene moiety to hydrocarbons, amination reaction, can be catalysed by metalloporphyrin complexes, that leads to chemo-, stereo-, and even enantioselectivity using any nitrene source. An extensive perspective on the subject was presented by Gallo et al. ${ }^{27}$

Nitrene transfer reactions (amination reactions) with the formation of aza-derivatives were catalysed by sandwich-type ruthenium(IV) $\mu$-oxo porphyrin complexes (Figure 14). ${ }^{28}$ The yields exceed 44\%, when using 2.6 $\times 10^{-5} \mathrm{~mol}$ catalyst $\left(1.0 \%\right.$ with respect to $\left.\mathrm{ArN}_{3}\right)$ under reflux of the substrate and in 0.5 to 6 hours interval. As mechanism is concerned, a bis-imido ruthenium(VI) intermediate is responsible for the nitrene transfer reaction. 


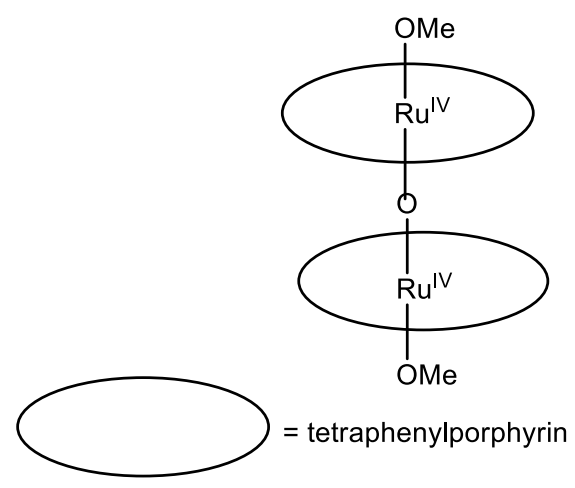

Figure 14. Sandwich-type ruthenium(IV) $\mu$-oxo porphyrin complexes.

The direct amidation of a wide range of aldehydes using [ $N$-( $p$-tolylsulfonyl)imino]phenyliodinane (Phl=NTs) as a nitrogen source was catalysed successfully by ruthenium(II)-tetratolyl-(CO)-porphyrins $[\mathrm{Ru}(\mathrm{TTP})(\mathrm{CO})]^{29}$ (Figure 15). The authors concluded that the amidation only occurs at the acyl $\mathrm{C}-\mathrm{H}$ bond of the starting aldehyde. The reaction conditions are mild; room temperature is acceptable, the yields vary from 68 to $99 \%$, and the molar ratio of catalyst: aldehyde: nitrogen source $=1: 10: 20$.

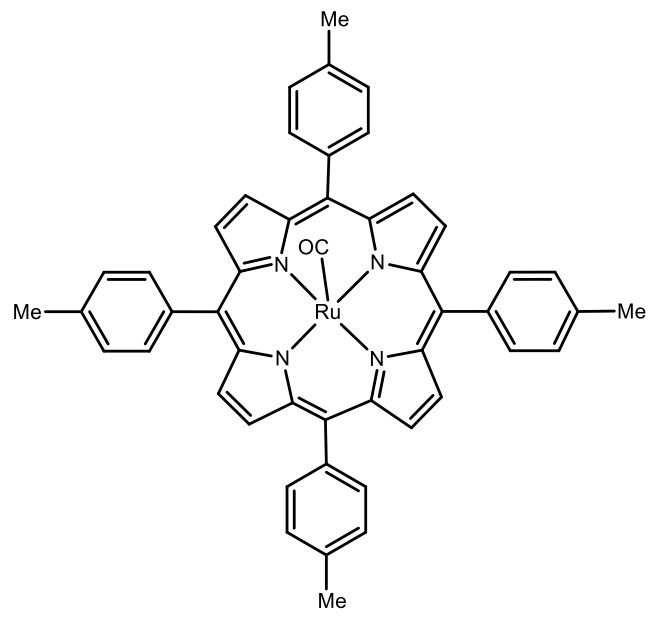

Figure 15. Ruthenium(II)-tetratolyl-(CO)-porphyrin.

Alkene aziridation with pentafluorophenyl azide (Scheme 7) required 0.5 mol\% Ru(IV)-[tetrakis(4-fluorophenyl)porphyrin)(1,3-dimethyl-2,3-dihydro-1H-benzimidazol-2-ylidene) ${ }_{2}$ (Figure 9) as catalyst, benzene as solvent, without heating. Yields between 92 and 99\% were obtained for several alkenes investigated, under these very mild conditions.

$$
\mathrm{R}^{1} \mathrm{R}^{2}+\left(\mathrm{C}_{6} \mathrm{~F}_{5}\right) \mathrm{N}_{3} \frac{\text { Ru-porphyrin catalyst }}{\text { benzene, } \mathrm{RT}, 12 \mathrm{~h}} \underset{\mathrm{R}^{1}}{\stackrel{\mathrm{R}^{2}}{\Lambda_{\mathrm{N}}-\mathrm{C}_{6} \mathrm{~F}_{5}}}
$$

Scheme 7. General alkene aziridination reaction.

Asymmetric aziridination of aromatic alkenes and asymmetric amidation of benzylic hydrocarbons was achieved using chiral ruthenium porphyrins feature aziridine selectivities for aromatic alkenes and amide 
selectivities for benzylic hydrocarbons. ${ }^{30}$ The porphyrin catalyst (Halterman porphyrin) (Figure 16) contains a sterically demanding $\mathrm{D}_{4}$-symmetric chiral ligand: 5,10,15,20-tetrakis- $\{(1 S, 4 R, 5 R, 8 S)-1,2,3,4,5,6,7,8$-octahydro1,4:5,8-dimethanoanthracene-9-yl\}porphyrin and two tosylimido axial ligands:

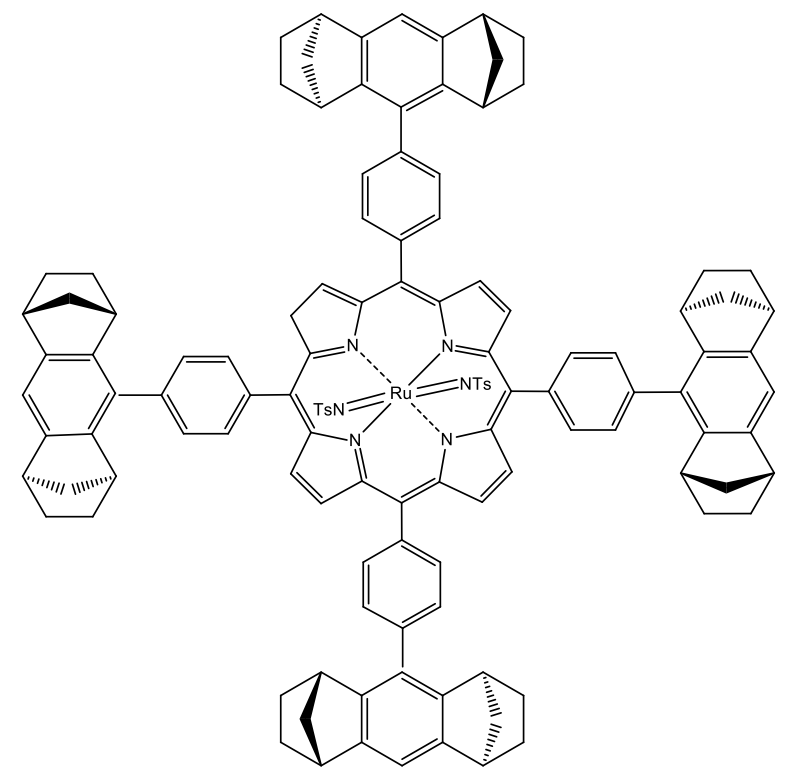

Figure 16. Halterman porphyrin.

Kinetic studies performed by the authors show a significant effect of the large porphyrin ligand on the nitrogen-atom-transfer reactions of bis(tosylimido)ruthenium(VI) porphyrins.

\subsection{Insertion reactions}

The ruthenium(II)-tetratolyl-(CO)-porphyrins $[\mathrm{Ru}(\mathrm{TTP})(\mathrm{CO})]^{29}$ were also tested as catalysts for carbene $\mathrm{X}-\mathrm{H}$ insertion reactions (Scheme 8). Good yields (over 55\%) were obtained for a series of substrates.

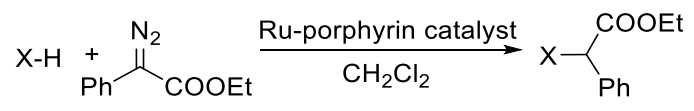

Scheme 8. General carbene X-H insertion reaction.

For example, the reaction between ethyl 2-diazo-2-phenylacetate and thiophenol gave $98 \%$ yield when using 2 mol\% Ru(IV)-tetra-(4-fluorophenyl)porphyrin)(1,3-dimethyl-2,3-dihydro-1H-benzimidazol-2-ylidene) 2 (Figure 9) as catalyst and dichloromethane as solvent. The reaction was completed in four hours, at room temperature.

In order to obtain more active and less oxygen-sensitive catalyst for carbene transfer reactions, the modification of wild-type myoglobin $(\mathrm{Mb})$ through the insertion of a Ru mesoporphyrin IX into the active site was performed. ${ }^{31}$ The experiments proved that the obtained RuMb can be an effective catalyst for $\mathrm{N}-\mathrm{H}$ insertion and for carbene transfer reactions, but has less stability and a reduced lifetime compared to the ironcontaining analogues.

Ru(IV)-meso-tetrakis(pentafluorophenyl)-porphyrin chloride (Figure 17) can catalyse inter- and intramolecular nitrene insertion into $\mathrm{sp}^{3} \mathrm{C}-\mathrm{H}$ bonds of hydrocarbons in good to high product yields using 
phosphoryl azides as nitrene sources. ${ }^{32}$ The optimum reaction conditions are: phosphoryl azide $0.2 \mathrm{mmol}$; hydrocarbon 4 mmol (20 equiv.); ruthenium catalyst 2 mol\%; $4 \AA$ molecular sieves 100 mg; dichloroethane 3 $\mathrm{mL}$; argon, reflux; $12 \mathrm{~h}$.

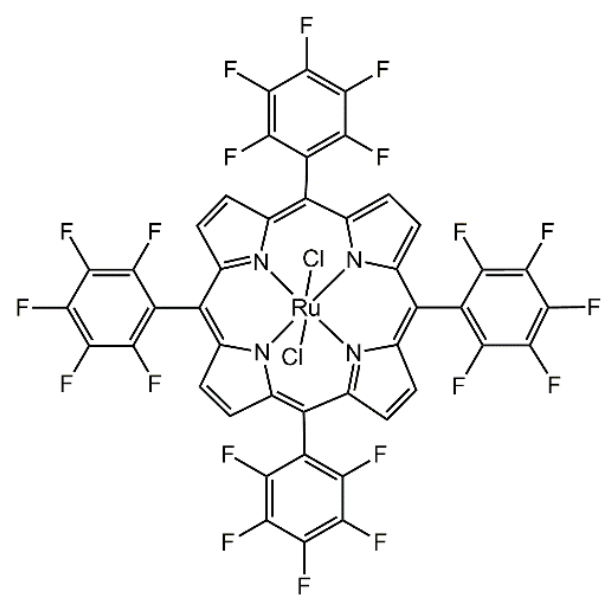

Figure 17. Ru(IV)-tetra(pentafluorophenyl)-porphyrin chloride.

Nitrene insertion into saturated $\mathrm{C}-\mathrm{H}$ bonds with pentafluorophenyl azide was also obtained using 0.5 mol\% Ru(IV)-tetra-(4-fluorophenyl)porphyrin)(1,3-dimethyl-2,3-dihydro-1H-benzimidazol-2-ylidene) 2 (Figure 9) catalyst, dichloromethane as solvent and 12 hours reflux yielded over $88 \%$ product, when tested on different aliphatic and aromatic substrates, from cyclohexane (90\%) to 1,2,3,4-tetrahydronaphthalene (96\%).

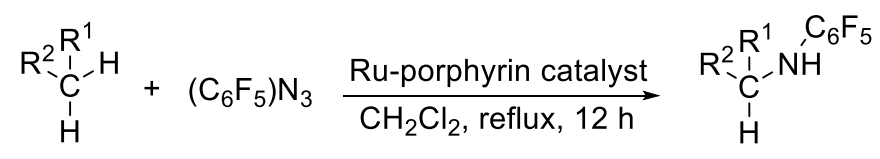

Scheme 9. General nitrene insertion reaction.

\subsection{Oxidation reactions}

A complex and detailed study performed by Gross and Ini ${ }^{33}$ concerning the intermediate species that have definitive role in the epoxidation reaction of olefins by aromatic $N$-oxides catalysed by ruthenium-porphyrins, established that the $\mathrm{N}$-oxide-coordinated oxoruthenium(IV) complexes are the most reactive as well as most selective intermediates.

Enantioselective epoxidation reactions of 3 -alkenylquinolones were achieved with the three chiral ruthenium porphyrin complexes shown in Figure $18 .^{34}$

Compound 1 (Figure 25) exhibited excellent catalytic properties in the enantioselective epoxidation of 3vinylquinolone ( $95 \%$ ee with a $1 \mathrm{~mol} \%$ catalyst loading), and by comparison to catalyst 2 (Figure 18), it could be shown that the enantioselectivity is due to the presence of two hydrogen bonding sites at a chiral bifunctional ligand. 


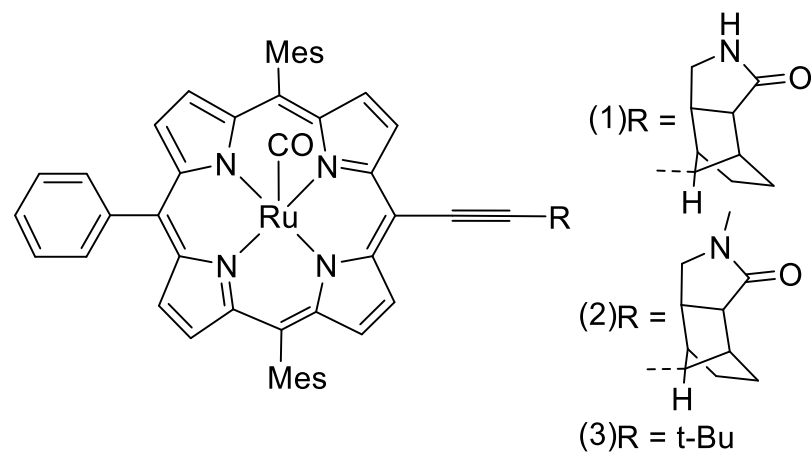

Figure 18. Ruthenium porphyrin complexes.

As $\operatorname{Ir}($ III)-porphyrins have the capacity to bind axial ligands that can modulate the electronic properties of the metal ion, introducing $\mathrm{N}$-heterocyclic carbene $(\mathrm{NHC})$ ligands into the axial position of $\operatorname{Ir}(\mathrm{III})$-porphyrins, modifies the photophysical properties of the obtained compounds such as: split Soret bands, broadened and redshifted absorption and emission spectra and substantially reduced emission quantum yield and lifetime. ${ }^{35}$ A deformation of the porphyrin ring takes place in order to relieve the steric repulsion between the NHC ligands and the porphyrin ring. Bis-NHC complexes: bis(1,3-dimethyl-2,3-dihydro-1H-imidazol-2-ylidene)(tetratolylporphyrinato)iridium [Ir(ttp)(IMe) $]^{+}$(Figure 19), and bis(1,3-dimethyl-2,3-dihydro-1H-benzimidazol2-ylidene)-(2,3,7,8,12,13,17,18-octaethylporphyrinato)-iridium $\left[\operatorname{Ir}(\mathrm{oep})(\mathrm{BIMe})_{2}\right]^{+}$are able to catalyse the photoinduced aerobic oxidation of a variety of secondary amines and arylboronic acids. Conditions for secondary amine oxidation: dibenzylamine $(0.1 \mathrm{mmol})$ and catalyst $(0.1 \mathrm{mmol})$ in $\mathrm{MeCN}(1.5 \mathrm{~mL}), \mathrm{O}_{2}$ bubbling, xenon lamp (>400 $\mathrm{nm}$ ). Using the bulkier Ir-porphyrin compound [Ir(oep)(BIMe) $]^{+}$led to a better yield (99\%) as compared to the $92 \%$ obtained for the $\left[\operatorname{Ir}(\operatorname{ttp})(\operatorname{IMe})_{2}\right]^{+}$counterpart. Conditions for arylboronic acid oxidation: arylboronic acid $(0.1 \mathrm{mmol})$, diisopropylamine $(0.4 \mathrm{mmol})$ and $\left[\mathrm{Ir}(\mathrm{oep})(\mathrm{BIMe})_{2}\right]^{+}(0.5 \mathrm{mmol})$ in DMF $(1.5 \mathrm{~mL}), \mathrm{O}_{2}$ bubbling, xenon lamp (>400 nm), when $100 \%$ conversion was registered.

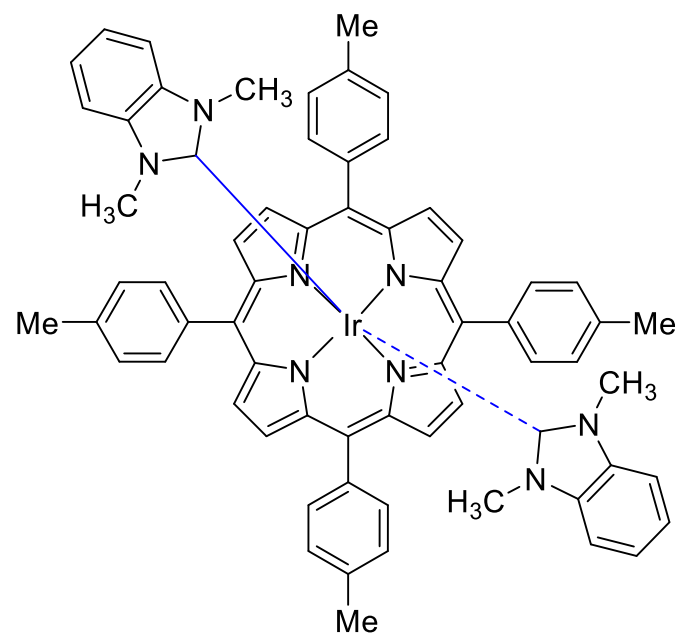

Figure 19. Bis(1,3-dimethyl)-2,3-dihydro-1H-imidazol-2-ylidene)-(tetratolylporphyrinato)-iridium. 


\section{Hydrogen Evolution and Water Oxidation Catalysed by Pt- and Pd-porphyrin Hybrids}

Solar-driven water splitting to produce $\mathrm{O}_{2}$ and $\mathrm{H}_{2}$ by means of photoelectrochemical cells represents an alternative source of fuels for the future. To perform this task, the cells must contain a material capable of light harvesting, one for catalysing light-driven water oxidation and one for proton reduction. ${ }^{36}$

A Pt(II)-triphenylporphyrin with a 2-bromopropionate group attached to the fourth phenyl substituent in meso position in order to restrain $\mathrm{H}$-aggregation (Figure 20) was assembled onto multiwalled carbon nanotubes. ${ }^{37}$ The hybrid material was tested as electrocatalyst for the hydrogen evolution reaction (HER). The as-prepared composites exhibit superior HER catalytic activity with an overpotential of $35 \mathrm{mV}$ for an electrocatalytic current density of $\mathrm{j}=-10 \mathrm{~mA} \mathrm{~cm}^{-2}$ and a Tafel slope of $32.3 \mathrm{mV} \mathrm{dec}{ }^{-1}$. Moreover, such catalysts do not exhibit observable activity decay after a 1000-cycle stability test, thus demonstrating their excellent durability.

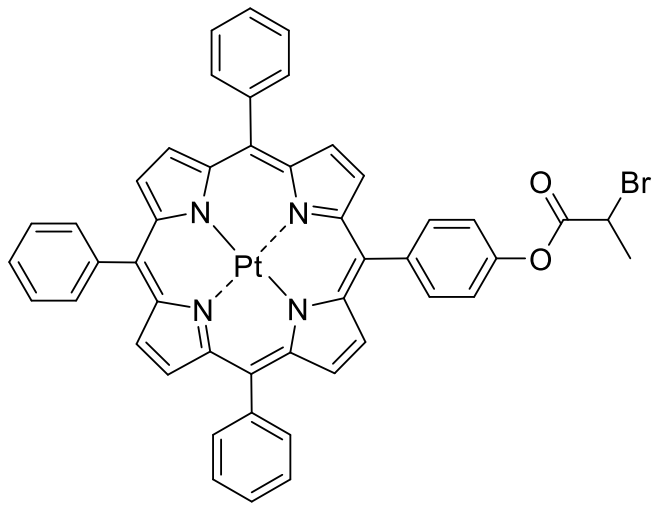

Figure 20. 5-[4-(2-Bromopropanoyloxy)phenyl]-10,15,20-triphenylporphyrin-Pt(II).

Among the photocatalysts that are able to convert solar energy into renewable fuels, gel catalysts present the advantage of large surface areas and allow for the adsorption and dissociation of water. ${ }^{38}$ The authors obtained porphyrin-imine gels by reacting 5,10,15,20-tetrakis( $p$-aminophenyl)porphyrin and its $\mathrm{Pd}$ and $\mathrm{SnCl}_{2^{-}}$ metallated derivatives with 1,3,5-tris-(4-formylphenyl)triazine (TFPT). The amine groups of the porphyrin act as functional ends for the bond with polymeric imine gels. The nanomaterials were completely morphologically characterized and then used as photocatalysts for hydrogen evolution in an aqueous system using ascorbate as sacrificial electron donor and platinum as cocatalyst. It was concluded that the gel containing the porphyrin base had the lowest hydrogen production rate, of only of $29 \mu \mathrm{mol} \mathrm{h}^{-1} \mathrm{~g}^{-1}$, the wet gel containing Snporphyrin showed continuous and stable hydrogen production of only $65 \mu \mathrm{mol} \mathrm{h}{ }^{-1} \mathrm{~g}^{-1}$ during continuous $24 \mathrm{~h}$ visible light illumination $(\lambda>420 \mathrm{~nm}$ ), whereas the imine gel containing Pd-porphyrin and Pt cocatalyst (Ptdoped PdTAPP-TFPT) presented a rate of $671 \mu \mathrm{mol} \mathrm{h}^{-1} \mathrm{~g}^{-1}$ in the same conditions. The production of hydrogen photocatalyzed by Pt-doped PdTAPP-TFPT was continuous for 4 runs and presented a good stability.

The need for more photostable photosensitizers able to initiate the oxidation of water in phosphate buffer determined Brouwer et al. ${ }^{39}$ to design a three-component system, in which Pt(II)-tetra(4-carboxyphenyl)porphyrin or the corresponding tetramethyl ester act as photoanode, in combination with both homogeneous (Ir-NHC and $\mathrm{Co}_{4} \mathrm{O}_{4}$-cubane complexes) and heterogeneous water oxidation catalysts $\left(\mathrm{IrO}_{\mathrm{x}} \cdot \mathrm{nH}_{2} \mathrm{O} \sim 2 \mathrm{~nm}\right.$ and $\mathrm{Co}_{3} \mathrm{O}_{4}$ nanoparticles, $\sim 50 \mathrm{~nm}$ ) and sodium persulfate as sacrificial electron acceptor. 
It was concluded that Pt(II)-meso[tetra(4-methoxycarbonyl)phenyl]porphyrin has three times the photon capture ability and $240 \mathrm{mV}$ more oxidizing power than the extensively used tris(2,2'-bipyridyl)ruthenium(II) $\left[\mathrm{Ru}(\mathrm{bpy})_{3}{ }^{2+}\right]^{40}$

In the desire to create better supported catalysts for an improved photocatalytic $\mathrm{H}_{2}$ evolution in which the loading of the active ingredient can be increased, without the prospect of its aggregation due to thermal instability, a two-dimensional metal-organic framework (MOF) coordinating the catalyst in ultrahigh concentration was designed. ${ }^{41}$ The MOF was obtained by a bottom-up coordination procedure using $\mathrm{Pt}(\mathrm{II})$ tetrakis(4-carboxyphenyl)porphyrin as a linker and $\mathrm{Cu}_{2}(\mathrm{COO})_{4}$ paddle-wheel clusters as the metal nodes and polyvinyl pyrrolidone (PVP) as surfactant. PVP attached on the surface of the formed MOF and could prevent the stacking, favouring the formation of thin MOF sheets. These provide accessible active sites and higher photocatalytic performance due to the prevention of undesired electron-hole recombination. The Pt content was determined to be $12.0 \mathrm{wt} \%$. Water splitting photocatalyzed by these Pd-catalyst loaded MOF sheets under visible light irradiation $(\lambda>420 \mathrm{~nm}$ ) and using ascorbic acid as sacrificial agent produced hydrogen at a rate of $11320 \mu \mathrm{mol} \cdot \mathrm{g}^{-1} \cdot \mathrm{h}^{-1}$, that is significantly higher that other MOF-based photocatalysts, and the material could be recycled four times without significant loss of activity. The material also presents high dispersity in ethanol and can be drop-cast in thin films onto solid substrates without loss of activity.

The synergetic effect between Pd-porphyrin photosensitizers and Pt-NP cocatalysts confined within nanoscale coordination interspaces incorporating hydrophilic $\mathrm{Hf}(\mathrm{IV})$-oxo clusters ${ }^{42}$ led to a $\mathrm{H}_{2}$ evolution rate of $22674 \mu \mathrm{mol} \cdot \mathrm{g}^{-1} \cdot \mathrm{h}^{-1}$ with turn-over number (TON) of 4131.2 in $32 \mathrm{~h}$ and highest turn-over frequency (TOF) of $482.5 \mathrm{~h}^{-1}$. The Pd-porphyrin metalorganic framework was obtained hydrothermally from Pd(II)-tetrakis-(4carboxyphenyl)porphyrin and $\mathrm{HfCl}_{4}$ and into this network PtNPs were introduced. The obtained hybrid nanomaterial was morphologically and electrochemically characterized and its excellent performance determined the presentation of a reaction mechanism: under visible light excitation, the electrons transfer from the LUMO of Pd-porphyrin ligand to Pt-NPs, where the $\mathrm{H}_{2} \mathrm{O}$ molecules were reduced to generate $\mathrm{H}_{2}$. On the other hand, the $\mathrm{Hf}(\mathrm{IV})$-based MOF provided hydrophilic $\mathrm{Hf}\left(\mathrm{IV}\right.$ )-oxo clusters with $\mathrm{H}_{2} \mathrm{O}$ accumulation for photocatalytic water splitting.

\section{Conclusions}

While porphyrin platinic metal complexes catalyze a range of useful organic transformations, including $\mathrm{C}-\mathrm{C}$ bond forming reactions, they excel at the oxidation and functionalization of hydrocarbonate substrates for which there exist few alternative catalysts. Combined with light harvesting moieties, they allow for water splitting, thus providing a potentially viable and commercially attractive alternative to electrolysis. Furthermore, essentially quantitative and highly selective oxidations of hydrocarbons with solid-supported porphyrin complexes provide an entry into industrially useful intermediates under milder conditions and with excellent atom economy. Achieving similar milestones in the corresponding amination reactions would only increase the attractiveness of these catalysts.

However, in order to realize the full potential of such applications, combined synthetic and engineering teamwork is needed to increase the range of substrates amenable to such transformations, improve the efficiency of the electron transfer reactions, the robustness of the catalysts under practical scenarios, and demonstrate economically feasible implementation at scale. 


\section{Acknowledgements}

This research is funded by UEFISCDI, project ECOTECH-GMP 76 PCCDI/2018, belonging to PNIII-Future and Emerging Technologies and partially by the Romanian Academy through Program 3/2020 from the Institute of Chemistry "Coriolan Dragulescu".

\section{References}

1. Mironov, A. Handbook of Porphyrin Science 2012, 18, 303-413.

https://doi.org/10.1142/9789814335508 0012

2. Wan, Q.-X.; Liu, Y. Catal. Lett. 2008, 128, 487-492.

https://doi:10.1007/s10562-008-9780-2

3. Rao, K. U.; Lakshmidevi, J.; Appa, R. M.; Prasad, S. S.; Narasimhulu, M.; Vijitha, R.; Rao K.S.V.K.; Venkateswarlu, K. Chemistry Select 2017, 2, 7394-7398.

https://doi:10.1002/slct.201701413

4. Zhang, J.; Zhao, G.-F.; Popović, Z.; Lu, Y.; Liu, Y. Mater. Res. Bull. 2010, 45, 1648-1653. https://doi:10.1016/j.materresbull.2010.07.006

5. Venkateswarlu, K.; Rao, K. Synlett 2018, 29, 1055-1060.

https://doi:10.1055/s-0036-1591549

6. Kostas, I. D.; Coutsolelos, A. G.; Charalambidis, G.; Skondra, A. Tetrahedron Lett. 2007, 48, 6688-6691. https://doi:10.1016/i.tetlet.2007.07.141

7. Bahrami, K.; Kamrani, S. N. Appl. Organomet. Chem. 2017, 32, e4102.

https://doi:10.1002/aoc.4102

8. Fareghi-Alamdari, R.; Golestanzadeh, M.; Bagheri, O. RSC Advances 2016, 6(110), 108755-108767. https://doi:10.1039/c6ra21223a

9. Bagheri, O.; Sadegh, F.; Moghadam, M.; Tangestaninejad, S.; Mirkhani, V.; Mohammadpoor-Baltork, I.; Safiri, M. Appl. Organomet. Chem. 2014, 28, 337-346.

https://doi:10.1002/aoc.3131

10. Sadegh, F.; Bagheri, O.; Moghadam, M.; Mirkhani, V.; Tangestaninejad, S.; Mohammadpoor-Baltork, I. J. Organomet. Chem. 2014, 759, 46-57.

https://doi:10.1016/i.jorganchem.2014.02.006

11. Fujimoto, K.; Yoneda, T.; Yorimitsu, H.; Osuka, A. Angew. Chem. Int. Ed. 2013, 53, 1127-1130.

https://doi:10.1002/anie.201308551

12. Suijkerbuijk, B. M. J. M.; Herreras Martínez, S. D.; Koten, G. van; Klein Gebbink, R. J. M. Organometallics 2008, 27, 534-542.

https://doi:10.1021/om7005613

13. Venkateswarlu, K.; Rao, K. Synlett. 2018, 29, 1055-1060.

https://doi:10.1055/s-0036-1591549

14. Dela Cruz, J.; Ruamps, M.; Arco, S.; Hung, C.-H. Dalton Trans. 2019, 48, 7527-7531.

https://doi:10.1039/c9dt00104b

15. Xie, M.-H.; Yang, X.-L.; Wu, C.-D. Chem. Commun. 2011, 47, 5521.

https://doi:10.1039/c1cc10461f 
16. To, W.-P.; Liu, Y.; Lau, T.-C.; Che, C.-M. Chem. Eur. J. 2013, 19, 5654-5664. https://doi:10.1002/chem.201203774

17. Thompson, S. J.; Brennan, M. R.; Lee, S. Y.; Dong, G. Chem. Soc. Rev. 2018, 47, 929-981. https://doi:10.1039/c7cs00582b

18. Liu, J.; Fan, Y.-Z.; Li, X.; Wei, Z.; Xu, Y.-W.; Zhang, L.; Su, C.-Y. Appl. Catal. B. 2018, 231, 173-181. https://doi:10.1016/j.apcatb.2018.02.055

19. Sun, D.; Gao, Y.; Fu, J.; Zeng, X.; Chen, Z.; Li, Z. Chem. Commun. 2015, 51, 2645-2648. https://doi:10.1039/c4cc09797a

20. Epp, K.; Bueken, B.; Hofmann, B.; Cokoja, M.; Hemmer, K.; De Vos, D. E.; Fischer, R. A. Catal. Sci. Technol. 2019, 11, 6452-6459.

https://doi:10.1039/c9cy00893d

21. Chan, K.-H.; Guan, X.; Lo, V. K.-Y.; Che, C.-M. Angew. Chem. Int. Ed. 2014, 53, 2982-2987. https://doi:10.1002/anie.201309888

22. Nicolas, I.; Maux, P. L.; Simonneaux, G. Tetrahedron Lett. 2008, 49, 5793-5795. https://doi:10.1016/j.tetlet.2008.07.133

23. Kroitor, A. P.; Cailler, L. P.; Martynov, A. G.; Gorbunova, Y. G.; Tsivadze, A. Y.; Sorokin, A. B. Dalton Trans. 2017, 46, 15651-15655. https://doi:10.1039/c7dt03703a

24. Wang, H.; Wan, Q.; Low, K.-H.; Zhou, C.; Huang, J.-S.; Zhang, J.-L.; Che, C.-M. Chem. Sci., 2020, 11, 2243. https://doi:10.1039/c9sc05432d

25. Che, C.-M.; Huang, J.-S. Coord. Chem. Rev. 2002, 231, 151-164. https://doi:10.1016/s0010-8545(02)00117-0

26. Wang, C.; Shalyaev, K. V.; Bonchio, M.; Carofiglio, T.; Groves, J. T. Inorg. Chem. 2006, 45, 4769-4782. https://doi:10.1021/ic0520566

27. Fantauzzi, S.; Caselli, A.; Gallo, E. Dalton Trans. 2009, 28, 5434. https://doi:10.1039/b902929j

28. Zardi, P.; Intrieri, D.; Carminati, D. M.; Ferretti, F.; Macchi, P.; Gallo, E. J. Porphyr. Phthalocy. 2016, 20(08n11), 1156-1165. https://doi:10.1142/s1088424616500814

29. Chang, J. W. W.; Chan, P. W. H. Angew. Chem. Int. Ed. 2008, 47, 1138-1140. https://doi:10.1002/anie.200704695

30. Liang, J.-L.; Huang, J.-S.; Yu, X.-Q.; Zhu, N.; Che, C.-M. Chem. Eur. J. 2002, 8, 1563-1572. https://doi:10.1002/1521-3765(20020402)8:7<1563::AID-CHEM1563>3.0.CO;2-V

31. Wolf, M. W.; Vargas, D. A.; Lehnert, N. Inorg. Chem. 2017, 56(10), 5623-5635. https://doi:10.1021/acs.inorgchem.6b03148

32. Xiao, W.; Wei, J.; Zhou, C.-Y.; Che, C.-M. Chem. Commun. 2013, 49, 4619. https://doi:10.1039/c3cc41110a

33. Gross, Z.; Ini, S. Inorg. Chem. 1999, 38, 1446-1449. https://doi:10.1021/ic9810211

34. Fackler, P.; Huber, S. M.; Bach, T. J. Am. Chem. Soc. 2012, 134, 12869-12878. https://doi:10.1021/ja305890c

35. Lam, T. L.; Ka Chung, T.; Yang, C.; Kwong, W.-L.; Guan, X.; Li, M.-D.; Lo, V. K.-Y.; Chan, S. L.-F.; Phillips, D. L.; Lok, C.-N.; Che, C.-M. Chem. Sci. 2019, 10, 293-309. https://doi:10.1039/c8sc02920b 
36. Shen, S.; Lindley, S. A.; Dong, C.; Chen, E.; Lu, Y.; Zhou, J.; Hu, Y.; Wheeler, D.A.; Guo P.; Zhang J.Z.; Kliger D.S.; Mao, S. S. Solar RRL, 2018, 1800285.

https://doi:10.1002/solr.201800285

37. Wang, L.; Zhang, Z.; Li, M.; Li, Q.; Wang, B.; Wang, S.; Zhou, H.; Mao, B. ChemCatChem 2020, https://10.1002/cctc.202000104

38. Liao, P.; Hu, Y.; Liang, Z.; Zhang, J.; Yang, H.; He, L.-Q.; Tong Y-X.; Liu, J.-M.; Chen, L.; Su, C.-Y. J Mat. Chem. A 2018, 6, 3195-3201.

https://doi:10.1039/c7ta09785a

39. Chen, H.-C.; Hetterscheid, D. G. H.; Williams, R. M.; van der Vlugt, J. I.; Reek, J. N. H.; Brouwer, A. M. Energy Environ. Sci. 2015, 8, 975-982.

https://doi:10.1039/c4ee03302g

40. Wacholtz, W. F.; Auerbach, R. A.; Schmehl, R. H. Inorg. Chem. 1986, 25, 227-234. https://doi:10.1021/ic00222a027

41. Zuo, Q.; Liu, T.; Chen, C.; Ji, Y.; Gong, X.; Mai, Y.; Zhou, Y. Angew. Chem. Int. Ed. Engl. 2019, 58, 1019810203. https://doi:10.1002/ange.201904058

42. Li, S.; Mei, H.-M.; Yao, S.-L.; Chen, Z.; Lu, Y.-L.; Zhang, L.; Su, C.-Y. Chem. Sci. 2019, 10, 10577-10585. https://doi:10.1039/c9sc01866b

\section{Author's Biography}

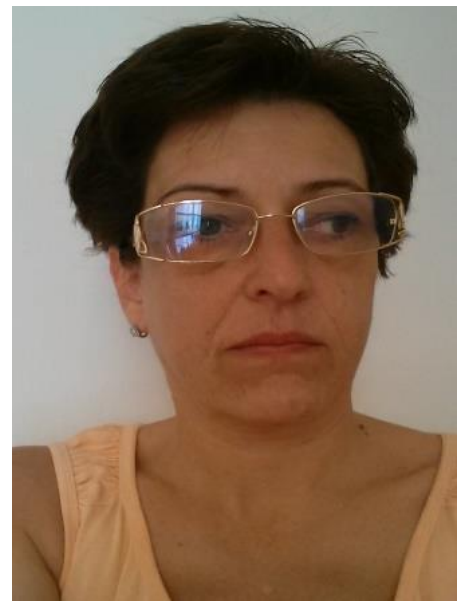

Lascu Anca is currently third-degree scientific researcher at the Institute of Chemistry "Coriolan Dragulescu" Timisoara of the Romanian Academy. She graduated Industrial Chemistry and Environmental Engineering Faculty, Timisoara, Romania in 1992 as chemical engineer and was awarded PhD title in 2010 in chemistry. Since 2013 she has been involved in research of porphyrin synthesis and applications. 